\title{
Implementing a protocol for selection and prioritisation of organic contaminants in the drinking water value chain: Case study of Rand Water, South Africa
}

\author{
EJ Ncube ${ }^{1,2 *}, \mathrm{~K}$ Voyi $^{2}$ and $\mathrm{H}_{\text {du Preez }} \mathrm{z}^{1,3}$ \\ ${ }^{1}$ Rand Water, Scientific Services Division, PO Box 1170, Johannesburg, 2000, South Africa \\ ${ }^{2}$ School of Health Systems and Public Health, Faculty of Health Sciences, University of Pretoria, Pretoria, 0002, South Africa \\ ${ }^{3}$ Department of Zoology, University of Johannesburg, PO Box 17011, Johannesburg 2028, South Africa
}

\begin{abstract}
Approaches that prioritise chemicals according to their importance as environmental contaminants have been developed by government agencies and private industries. However, it has been noticed that few approaches, such as one published by the United States Environmental Protection Agency (USEPA), address the needs of the drinking water industry. There is also no generic approach to the selection, prioritisation and monitoring of organic contaminants in the drinking water value chain. To safeguard drinking water industry customers, it was necessary to develop a generic protocol to assist with the identification of a list of organic contaminants for monitoring in the drinking water value chain. Once the protocol was developed, it was validated in a prototype drinking water value chain. This paper describes the implementation of such a generic protocol. The exercise comprised of testing each step of the protocol, from selection of the 'pool of organic contaminants' (Step I) to recommending the final priority list of organic contaminants (Step VII). Successful implementation of the protocol took place in the Rand Water (South Africa) drinking water value chain (from catchment to tap). Expert judgment was emphasized during the implementation as each step was validated and the opinion of key stakeholders used to shape the process. The tailor-made prioritisation criteria, reflecting the drinking water industry perspective, proved to be successful in selecting and prioritising organic contaminants for monitoring in the drinking water value chain. The organic contaminants were successfully prioritised in 3 classes: short-term priority for analysis, medium-term priority for analysis and long-term priority for analysis. This is a very important guide to assist water utilities in optimising their resources while not compromising the role of public health protection. Finally, a priority list of organic contaminants was identified for use by Rand Water and other water utilities.
\end{abstract}

Keywords: generic protocol, organic contaminants, validation, selection and prioritisation, drinking water value chain, expert judgment

\section{Introduction}

Today's vast chemical industry and particularly its giant offspring, the production of synthetic organic chemicals (Middleton and Rosen, 1956), have introduced new challenges to the scientists and public officers engaged in providing and protecting public health through the provision of safe drinking water. This challenge was noticed more than half a century ago (Middleton and Rosen, 1956). Industrial contamination of water, while important, is not the only factor to consider in the complex organic pollution situation. Domestic sewage, natural run-off and materials derived from the life cycle of aquatic plants and animals contribute substantial quantities of organic materials to streams. (Meintjes et al., 2000; Kolpin et al., 2004; Cheevaporn et al., 2005; Voutsa et al., 2006; Ellis, 2006) This observation has resulted in recent research efforts being focused on organic contaminants (Zimmerman, 2005; Karthikeyan and Meyer, 2006; Rissato et al., 2006; Weber et al., 2006; Rowe et al., 2007; Kim et al., 2007; Kumar et al., 2008). The major outcome from this has been the detection of a number of more classic organic contaminants as well as the

\footnotetext{
* To whom all correspondence should be addressed.

욤 +27 164308463 ;

e-mail: encube@randwater.co.za

Received 25 July 2011; accepted in revised form 9 July 2012.
}

so-called 'emerging organic contaminants' (Kaj et al., 2005; Colvin, 2006; Richardson et al., 2002; Loganathan et al., 2007; Haukas et al., 2007; Miège et al., 2008; Oberdörster et al., 2006). Another challenge is the indication that most organic wastewater contaminants are not completely removed during conventional wastewater and drinking water production processes (Rodriguez-Mozaz et al., 2006; Majam and Thompson, 2007; Kim et al., 2007; Stackelberg et al., 2007; Miège et al., 2008; Balest et al., 2008; Okuda et al., 2008). Such contaminants might be present in drinking water distributed to the consumers and the number of organic contaminants of concern to the drinking water industry has increased.

Exposure of consumers to organic contaminants introduced during drinking water distribution, either from materials of construction or by process, needs to be assessed since consumers might have direct exposure. Such studies have been conducted (Kolpin et al., 2004; Ellis, 2006; Bolto and Gregory, 2007; Majam and Thompson, 2006; Majam and Thompson, 2007; Kim et al., 2007; Stackelberg et al., 2007; Miège et al., 2008). It is therefore necessary to identify organic contaminants with the potential of entering into surface and groundwater sources, being introduced into the treatment process, surviving the treatment process or being formed as impurities and/or by-products during the treatment process. This includes substances released into treated water due to leaching from distribution material, such as reservoir linings, pipelines, and/ or released from household plumbing systems into the final 
drinking water. Consumers might also be exposed to organic contaminants at the point of use through activities such as bathing and washing (Cheevaporn et al., 2005).

The concerns of the drinking water industry include potential adverse health effects these organic contaminants are capable of causing, potential damage to infrastructure, and impairment of the acceptability of drinking water to consumers. Among those known are the production of offensive tastes and odours in water (Carmichael et al., 2001; Du Preez and Van Baalen, 2006), interference with treatment of water for industrial and domestic use (Majam and Thompson, 2006), and causing of adverse health effects to non-target aquatic organisms and human health (Calderon, 2000; Cooper et al., 2000; WHO, 2004; Wiegand and Pflugmacher, 2005; Rier and Foster, 2002; Zhu et al., 2006; Voulvoulis, 2004; Sharpe, 2003; Webb et al., 2003; Jones et al., 2005; Gopal et al., 2007). Well-known adverse health effects of concern include various cancers, mutagenicity, teratogenicity, reproductive effects, toxicity and endocrine disruption (Burger, 2005). Consequently, monitoring for organic contaminants in the drinking water value chain (from source to tap) is becoming mandatory. It is therefore crucial that appropriate tools that will allow drinking water service providers to manage organic contaminants in the drinking water value chain be developed. The tool should allow the service provider to select and prioritise those priority organic contaminants of concern to drinking water and public health.

Approaches that prioritise chemicals according to their importance as environmental contaminants have been developed by government agencies and private industries such as the United Kingdom's Institute for Environmental Health (IEH) (IEH, 2004), the European Community's Oslo and Paris (OSPAR) Convention exercise for the protection of the Northeast Atlantic marine environment (EC, 2000; EAWAG, 2002), the European Union (EU)'s combined monitoring-based and modelling-based priority-setting scheme (EU-COMMPs) (Klein et al., 1999) and the United States Environmental Protection Agency (USEPA) (USEPA, 2000; EAWAG, 2002; USEPA, 2008). These approaches have illustrated how the complex and often contentious task of identifying, ranking and culling multitudes of substances to result in much smaller numbers that will receive regulatory and research consideration has been approached in various countries. They also serve to illustrate how stakeholder consultation and expert judgment is vital and integral to the design, implementation and validation of these types of prioritisation schemes. However, shortcomings are apparent. Few approaches address the needs of the drinking water industry and there is no generic approach to the selection, prioritisation and monitoring of organic contaminants in the drinking water value chain. This has led to poor regulation of organic contaminants in drinking water, especially in developing countries.

To address these shortcomings, Ncube et al., (2011) developed a generic protocol for the selection and prioritisation of organic contaminants for monitoring in the drinking water value chain (from source to tap) (Fig. 1). This protocol was implemented in a prototype drinking water value chain. The framework within which the protocol was developed consisted of 3 major steps: the selection of the 'pool of contaminants', screening, and prioritisation. For each step criteria reflective of the needs of the drinking water industry, being mainly to protect human health and integrity of the water supplied to consumers, was used. The protocol aimed to identify priority organic contaminants for monitoring in the drinking water value chain (from source to tap). In addition, this protocol served to identify the importance of expert judgment in this type of exercise, proposing tailor-made criteria for prioritising organic contaminants and challenges faced by the industry in monitoring for organic contaminants in environmental samples. Hence, the main criteria used were based on the potential of organic contaminants to occur in the drinking water value chain, potential to cause human health effects, availability of standards and guidelines to allow for the regulation of organic contaminants in drinking water, capacity for removal, ease of monitoring in the drinking water value chain, potential of contaminant to cause aesthetic water quality problems such as taste, discolouration and odour, and the potential to increase the customer perception of risk. The objective of this paper is to present the approach used to prioritise the organic contaminants, the outcome of implementing each step from selection to prioritisation, and the priority organic contaminants recommended for use by a case-study drinking water service provider, Rand Water (South Africa) and other water utilities.

\section{Description of study area}

Rand Water is a bulk water supplier which provides treated water to more than 12 million people. Rand Water's area of supply includes a distribution network of over $3056 \mathrm{~km}$ of large diameter pipeline, feeding 58 strategically-located service reservoirs (Fig. 1). Its customers include metropolitan municipalities, local municipalities, mines and industries and it supplies, on average, 3653 million litres of water to these customers daily. The water utility abstracts its source water from the Vaal Dam catchment. This catchment is mainly agricultural although other land-use activities such as coal mining, gold mining, fuel production, power-generation, urban and industrial development also occur. This could result in the release of organic contaminants into the catchment. A survey conducted by Bruwer et al. (1985, cited in Braune and Rogers, 1987) showed micro-organic contamination along the entire length of the Vaal River downstream of the Vaal Barrage. The survey also indicated evidence of bio-accumulation of polychlorinated biphenyls (PCBs) and chlorinated pesticides in fish. Van Steenderen et al. (1987, cited in Braune and Rogers, 1987) reported a high degree of organic contamination in the Vaal River below the Barrage to Parys. High levels of phenolic compounds were found. These compounds can cause serious taste and odour problems, especially after chlorination. Van Steenderen et al. (1987) investigated organic contamination between the Vaal Dam-Vaal River Barrage system. The investigation of organic contaminants between the Grootdraai Dam and Parys resulted in 25 organic compounds being identified. These included chlorinated benzenes, phenols, phthalates, saturated hydrocarbons, pesticides such as atrazine, $\gamma$-BHC, cholesterol and polynuclear aromatic hydrocarbons such as pyrene.

In the early 1980s, Rand Water did an extensive survey of all international organic criteria, compiled appropriate documents on the use of organic contaminants in its catchments and funded a workshop with a panel of experts in order to establish the usage of various compounds in South Africa and the possibility of any detrimental health effects on Rand Water consumers (Bailey et al., 1988). It was evident that limiting factors have been the lack of accurate information about the extent of pollution, lack of capacity and expertise for analysis and the absence of local guidelines and standards for regulation of organic contaminants in drinking water. Some of the research needs identified for the Vaal River Catchment were the establishment of an organic pollutant monitoring system, 


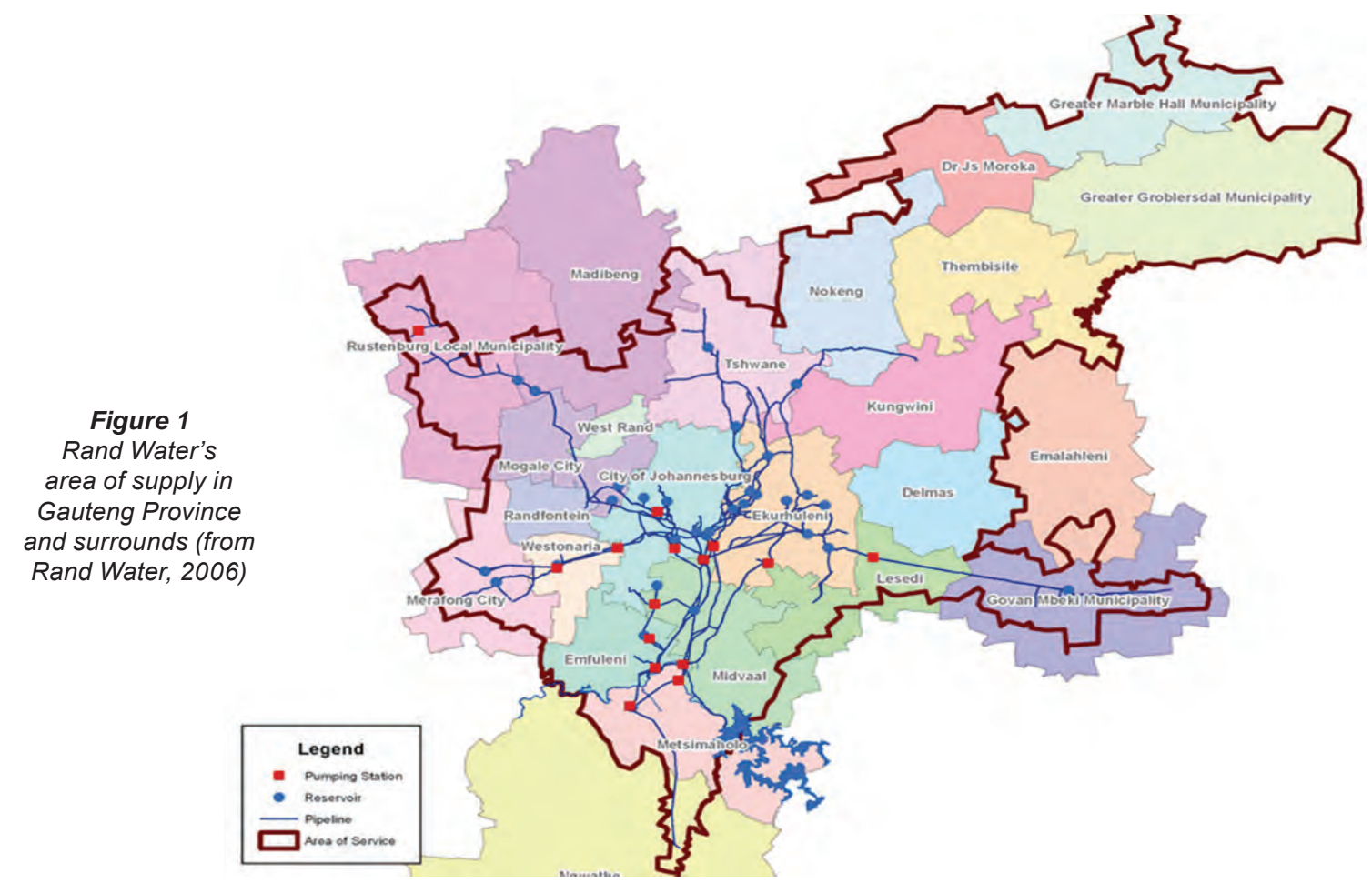

factors affecting water quality in the Vaal Dam and the effects of future management options on water quality and the accumulation of pesticides in the aquatic food chain (Braune and Rogers, 1987).

These identified research needs and the global actions on persistent organic pollutants (POPs) and suspected or potential endocrine-disrupting chemicals (EDCs) have since served as a catalyst for Rand Water management to re-kindle the efforts to address concerns of possible drinking water contamination by organic contaminants. These concerns were held by other role players in the water sector and relevant stakeholders such as the Department of Water Affairs (DWA), the Water Research Commission (WRC), other Water Boards, the Department of Agriculture, and universities who had started dialogue and research in the area. A study by Polder et al. (2008) indicated that higher concentrations of polybrominated diphenyl ethers (PBDEs) were measured in bird eggs from the Vaal River, which is situated downstream of the most industrialised area in South Africa (Polder et al., 2008). It is because of this context that Rand Water was chosen for validation of the protocol for the selection and prioritisation of organic contaminants for monitoring in the drinking water value chain.

\section{Application of the protocol}

This entailed the assessment of all of the steps illustrated in Fig. 2. A list-based approach was used in compiling the 'pool of contaminants'. Information, on naturally-occurring organic contaminants, known classical and 'emerging' organic contaminants, organic contaminants deliberately added into the drinking water during its treatment including known water treatment residues (WTR), restricted, banned and locally-used pesticides, was collated (Table 1). Four manuals on used pesticides and management of pests from the national Department of Agriculture were used to identify frequently-used pesticides (DoA, 2000; DoA 2002; DoA, 2003; DoA, 2004). The PAN-UK database for South Africa's registered list of pesticides was used for comparison and confirmation. The lists of regulated organic contaminants, such as endocrine-disrupting chemicals (EDCs), 'the EU list of priority substances for drinking water used for human consumption' and 'the dirty dozen' identified by the Stockholm Convention on Persistent Organic Pollutants (UNEP, 2001) were also considered. Organic contaminants appearing in drinking water quality guidelines or standards, such as the South African National Standard for drinking water SANS 241 (SABS, 2006), WHO guidelines for drinking water quality ( WHO, 2004), Health Canada drinking water quality guidelines (Health Canada, 2008), the USEPA list of regulated organic contaminants in drinking water (USEPA, 2008), organic contaminants in the Australian drinking water quality guidelines (NHMRC, 2004) and the New Zealand drinking water quality standards (MoH, 2008), were identified using the WHO guidelines as a benchmark. Interviews were conducted with various organisations to identify organic contaminants being analysed for. The information gathered from the interviews was checked against the 'pool of organic contaminants' or added accordingly. The resultant 'pool of contaminants' contained 600 organic compounds.

Once the 'pool of contaminants' was compiled, a workshop was conducted to determine the organic contaminants of possible concern. This was a qualitative exercise where the guiding principle was the relevance of the organic contaminants and their public health significance to the drinking water industry. During this step, similarities were noted and some organic contaminants were eliminated from the list based on the non-relevance to drinking water and the diversity of views and experience of the various experts. Some organic contaminants were adopted as being of concern, resulting in a 'Preliminary list of organic contaminants of possible concern (PLOCPC)' (Fig. 2). This resulted in 328 organic contaminants of possible concern remaining on the list. The screening of the preliminary list of organic contaminants of possible concern to drinking water was performed at 4 different levels (Fig. 2). This firstly involved conducting a literature survey, as it was 


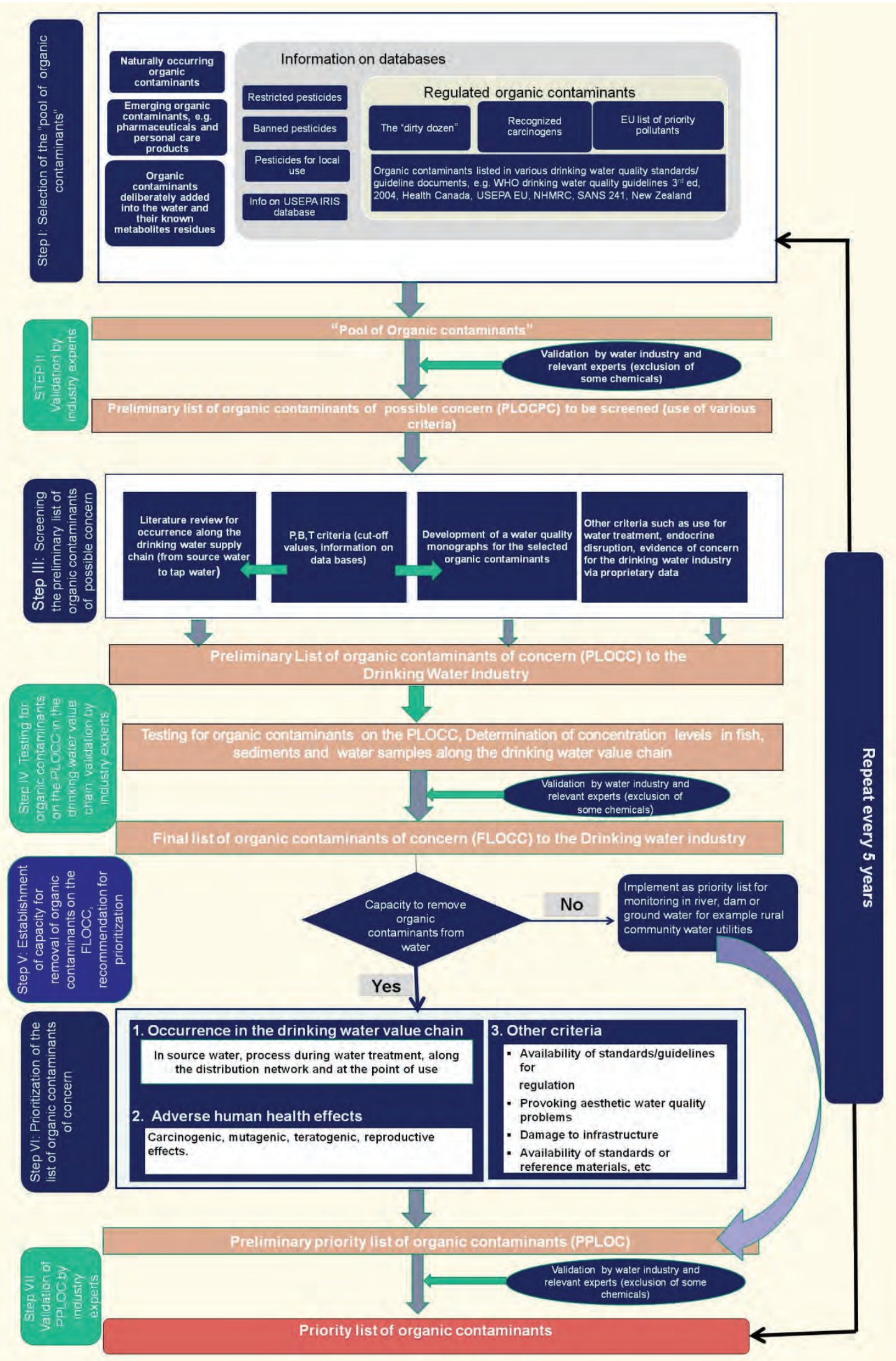

Figure 2

A generic protocol for the selection and prioritisation for organic contaminants for monitoring in the drinking water value chain 


\begin{tabular}{|c|c|c|}
\hline \multicolumn{3}{|c|}{$\begin{array}{c}\text { Table } 1 \\
\text { Information sources for compiling the 'pool of contaminants' }\end{array}$} \\
\hline Organisation & Information requested & Remarks \\
\hline Other water utilities & $\begin{array}{l}\text { Organic contaminants currently analysed for in } \\
\text { drinking water }\end{array}$ & BTEX, THMs, DOC, phenols \\
\hline Department of Agriculture & $\begin{array}{l}\text { Banned, restricted and frequently-used pesticides in } \\
\text { South Africa }\end{array}$ & $\begin{array}{l}\text { A set of } 4 \text { manuals on pesticides } \\
\text { used in South Africa for various } \\
\text { purposes was obtained. }\end{array}$ \\
\hline $\begin{array}{l}\text { Department of Environmental Affairs } \\
\text { and Tourism }\end{array}$ & $\begin{array}{l}\text { Africa Stockpiles Project implementation in South } \\
\text { Africa }\end{array}$ & The dirty dozen \\
\hline $\begin{array}{l}\text { The Department of Water Affairs, } \\
\text { National Toxicity Monitoring } \\
\text { Programme }\end{array}$ & Toxicants monitored in national water resources & The dirty dozen \\
\hline $\begin{array}{l}\text { The WHO guidelines for drinking } \\
\text { water quality, } 3^{\text {rd }} \text { edition, } 2004\end{array}$ & Organic contaminants of concern to public health & All listed organic contaminants \\
\hline $\begin{array}{l}\text { The PAN-UK list of registered pesti- } \\
\text { cides for South Africa }\end{array}$ & List of currently used, banned, restricted pesticides & $\begin{array}{l}\text { About } 500 \text { pesticides had been reg- } \\
\text { istered at the time of the study }\end{array}$ \\
\hline SANS 241:2006 & $\begin{array}{l}\text { List of organic parameters for analysis in drinking } \\
\text { water }\end{array}$ & DOC, phenols and THMs \\
\hline Health Canada & $\begin{array}{l}\text { List of organic parameters for analysis in drinking } \\
\text { water }\end{array}$ & $\begin{array}{l}\text { Listed organic contaminants of } \\
\text { concern }\end{array}$ \\
\hline New Zealand & $\begin{array}{l}\text { List of organic parameters for analysis in drinking } \\
\text { water }\end{array}$ & $\begin{array}{l}\text { Listed organic contaminants of } \\
\text { concern }\end{array}$ \\
\hline IARC & $\begin{array}{l}\text { List of organic contaminants 'recognised as human } \\
\text { carcinogens' }\end{array}$ & $\begin{array}{l}\text { Listed organic contaminants of } \\
\text { concern }\end{array}$ \\
\hline USEPA, IRIS database & $\begin{array}{l}\text { A list of organic compounds for which chronic } \\
\text { health hazard assessments for non-carcinogenic } \\
\text { effects have been done }\end{array}$ & $\begin{array}{l}\text { Listed organic contaminants of } \\
\text { concern }\end{array}$ \\
\hline EU Drinking Water Directive & $\begin{array}{l}\text { List of organic contaminants for analysis in water } \\
\text { used for human consumption }\end{array}$ & $\begin{array}{l}\text { Listed organic contaminants of } \\
\text { concern }\end{array}$ \\
\hline $\begin{array}{l}\text { EDCs for monitoring in drinking } \\
\text { water (South Africa) }\end{array}$ & List of EDCs & WRC Project KV 143/05 \\
\hline
\end{tabular}

Organic contaminants in the drinking water value chain (from source to tap)

evident that there might be more contaminants of concern to the drinking water industry. The list produced from the literature review was compared with the 'Preliminary list of organic contaminants of possible concern (PLOCPC)'. Some organic contaminants were eliminated at this stage based on the weight of evidence from the literature review. The compounds were arranged into a table according to their functional groups: organic contaminants of health concern via the drinking water ingestion route, dermal contact or inhalation, or those of aesthetic concern. Any evidence from the literature review was noted accordingly, as this would assist in decision-making in future steps. The main aim of the literature review was to identify organic contaminants with the potential for occurring in source water resources, at the plant during water treatment, along the distribution network and at the point of use.

The literature review revealed that organic contaminants that threaten source water quality include both naturally-occurring organic compounds and synthetic organic compounds. Natural organic contaminants include natural organic matter, humic substances, (Coelho-Souza et al., 2006; Frimmel, 1998; Klavinš et al., 2001) organometallics, (Pacheco et al., 2005; Leeuwen, 2000; Mahalingam, 2004), algal toxins and their microbial metabolites. Major groups of organic contaminants found in the literature were pesticides and their metabolites and pharmaceuticals and personal care products (PPCPs) (Kolpin et al., 2004; Karthikeyan and Meyer, 2006; Ellis, 2006; Kim et al., 2007; Stackelberg et al., 2007). Like the PPCPs, pesticides have been widely researched (Cheevaporn et al., 2005; Rissato et al., 2006; Zhang et al., 2004; Zhang et al., 2002; Wenzel et al., 2003). The various groupings of organic contaminants that occur in source water resources across the globe, as obtained from the literature review, are presented in Fig. 3.

\section{Organic contaminants from water treatment processes}

While the addition of chemicals to source water during drinking water production is beneficial, the general concern is the formation of water treatment residues (WTRs). WTRs are byproducts from drinking water production (Titshall and Hughes, 2005). WTRs from conventional water treatment processes consist mainly of the precipitated hydroxides of the treatment chemicals that are added to coagulate and flocculate dissolved and suspended material in the source water and also during the residue dewatering process (Titshall and Hughes, 2005). Some WTRs of concern include those introduced by the use of synthetic organic polymers as coagulant or flocculant aids (Bolto and Gregory, 2007; Niquette et al., 2004; Lee et al., 2004).

These structures may be polyelectrolytes, such as water-soluble flocculants or water insoluble ion exchange resins, or insoluble uncharged materials such as those used for plastic pipes and plastic trickling filter media. Polydiallyldimethyl ammonium chloride (PDADMAC) and epichlorohydrin-dimethylamine (epi-DMA) are established coagulants in the treatment of drinking water (Majam and Thompson, 2006). However, polyelectrolyte products used in the water supply industry may 


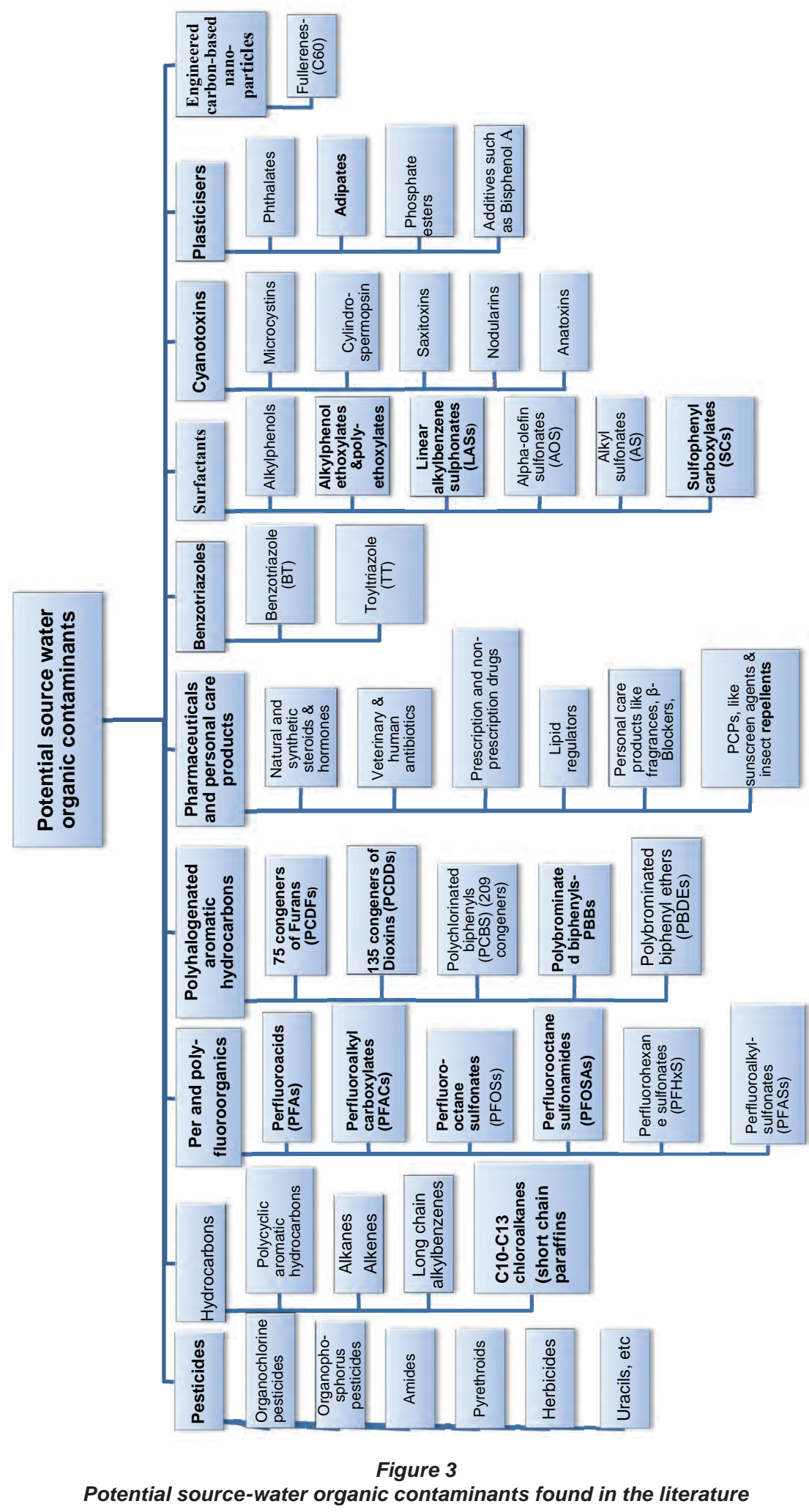

contaminants of concern into water systems (Bolto and Gregory, 2007; Kurenkov et al., 2003; Majam and Thompson, 2006; Lee et al., 2004; Chang, 2004). These include degradation of polyelectrolytes into other organic compounds of concern to human health, serving as precursors for the formation of disinfection byproducts which have potentially larger toxic effects on consumers than their parent compounds (Bolto and Gregory, 2007; Kurenkov et al., 2003; Majam and Thompson, 2006; Lee et al., 2004; Chang, 2004). Disinfection by-products of concern include nitrosodimethylamine (NDMA) (Bolto and Gregory, 2007) and a range of VOCs (Majam and Thompson, 2006).

Other organic contaminants formed during treatment processes include disinfection by-products (DBPs) of concern to the health of consumers. There is no doubt that chlorination has been successfully used for the control of waterborne infectious diseases for more than a century (Gopal et al., 2007). It has been confirmed that the chemical disinfection of water results in the formation of a wide variety and large number of DBPs (Simmons et al., 2004; Gopal et al., 2007; Richardson et al., 2002; Woo et al., 2002; Moudgal et al., 2000; Von Gunten, 2003). DBP profiles can vary with treatment methods (Schenck et al., 2004; Gopal et al., 2007). The number, chemical type and concentration of DBPs formed depends on source water characteristics such as: type and concentration of disinfectant, application point in the treatment process, type and concentration of organic matter in the water, $\mathrm{pH}$, temperature, and contact time with the disinfectant (Richardson, 2003). Halogenated trihalomethanes (THMs) and haloacetic acids (HAAs) are two major classes of DBPs commonly found in waters disinfected with chlorine. THMs (the combination of chloroform, bromodichloromethane, chlorodibromomethane and bromoform) and HAA5 (the 5 haloacetic acids: monochloro, dichloro-, trichloro-, monobromo-and dibromoacetic acids) are by-products of chlorination.

Bromate is a by-product of both disinfection with ozone and chlorine (Richardson, 2003). The challenge facing water-supply industry professionals

contain, in addition to polyelectrolyte, measurable amounts of certain contaminants. These contaminants are essentially unreacted raw material from the polyelectrolyte manufacturing process, for example monomer units, initiators and quenchers. The literature review focused on these types of organic contaminants.

Synthetic organic polymer use has resulted in concerns other than those of introducing impurities in parent compounds resulting in the release of residual monomers and other organic is how to simultaneously minimise the risk from microbial pathogens and disinfection by-products (Woo et al., 2002). New DBPs are also emerging as organic contaminants of concern (Richardson, 2003). Such DBPs include brominated and iodinated compounds such as bromonitromethanes, iodotrihalomethanes, iodo-acids and brominated forms of MX (3-chloro-4-(dichloromethyl)-5-hydroxy-2(5H)-furanone) (Richardson, 2003) as well as nitrosodimethyl-amine (NDMA). 


\section{Organic contaminants in distribution systems}

The distribution system is also a potential source of organic contamination of drinking water. Organic contaminants can enter supplies in several ways, that is, through leaching from plastic materials, application of renovation processes and permeation of certain plastic pipes, and microbial activity in biofilms (Hecq et al., 2006). Some introduction of organic chemicals from distribution systems is inevitable at some level, particularly in the early stages, such as with newly-laid pipe or after a recent renovation (Hecq et al., 2006). Excessive leaching of organic substances from pipe materials, linings, joining and sealing materials, coatings and cement mortar pipe have occasionally been noted in the literature (Hecq et al., 2006). High density polyethylene pipes (HDPE), cross-bonded polyethylene pipes (PEX) and polyvinylchloride (PVC) pipes for drinking water have been tested for leaching of contaminants (Skjevrak et al., 2003). A range of esters, aldehydes, ketones, aromatic hydrocarbons and terpenoids were identified as migration products from HDPE pipes (Skjevrak et al., 2003). Phthalamides have also been found to leach from blue MDPE, and this proved to be due to its presence as an impurity related to the blue pigment, copper phthalocyanine (Skjevrak et al., 2003). Organotins can leach into drinking water from certain types of polyvinyl chloride (PVC) pipes and PAHs, particularly fluoranthene, can leach from the older types of pipes which were lined with coal tar pitch (Skjevrak et al., 2003).

Permeation of polyethylene (PE) pipes by organic chemicals has been observed (Skjevrak et al., 2003). Leaching of organic compounds into water from reservoir/tank linings (Skjevrak et al., 2003) and the release of VOCs and SVOCs from natural biofilms in distribution networks has also been identified (Skjevrak et al., 2005). It has also been established that disinfection continues along the distribution network and new organic contaminants can be formed (Sadiq and Rodriguez, 2004). The residence time of water is one important parameter in explaining the fate of chlorinated disinfection by-products (CDBPs) (Sadiq and Rodriguez, 2004). Table 2 summarises the list of organic contaminants identified in the drinking water value chain. This list formed part of the 'preliminary list of organic contaminants of concern (PLOCC)' after applying the 'Persistence', 'Bioaccumulation' and 'Toxicity' (PBT) criteria (Step III, Fig. 2, Table 3).

Once the organic contaminants of possible concern were identified, further screening was done using information from available databases. From these sources, values for the physical properties and cut-off values characterising the 'Persistence', 'Bioaccumulation' and 'Toxicity' attributes were obtained. Based on the cut-off values, it was decided whether to exclude the organic contaminant or to add it to the 'preliminary list of organic contaminants of concern (PLOCC)' (Fig. 2). Values for each of the contaminants obtained from the above step were obtained from the literature, and using a 'yes' or 'no' decisionmaking process a contaminant was characterised as 'persistent' or 'not persistent', 'accumulative' or 'not accumulative' and 'toxic' or 'not toxic'. The same was done for other parameters.

Since not all of the organic contaminants had readily available data on the human exposure effects, fate and behaviour in the human body, measurement in environmental samples, removal methods from source water, drinking water quality guidelines or standards to enable regulation, it was necessary to develop water quality monographs at this stage (Ncube, 2009; Ncube et al., 2011). Water quality monographs were developed as an additional tool for screening the organic contaminants on the PLOCPC and those identified through the literature review. Completed water quality monographs were characterised by unique numbers. It was observed that the PLOCPC contained some organic contaminants which lacked a lot of information, especially on the PBT criteria, removal from water during treatment, fate and behaviour in the environment and drinking water regulation criteria among others. The organic contaminants which were identified for water quality monograph development were automatically placed on the list of organic contaminants of concern (Table 2). The organic contaminants listed in Table 2 were tested for occurrence in the drinking water value chain in Step IV of the protocol (Fig. 2).

\section{Testing for organic contaminants in a prototype drinking water value chain 'occurrence criterion'}

The occurrence criterion which was qualitatively applied in Step III by conducting a literature review was quantified during this step by testing for the occurrence of organic contaminants in the drinking water value chain. The 226 organic contaminants on the preliminary list of organic contaminants of concern (Table 2) obtained from Step III were assessed for occurrence in the Rand Water drinking water value chain. This was achieved by comprehensive laboratory analyses of organic contaminants in biota (fish tissue), sediments and water samples. The assessment was conducted twice a year during the low-flow (dry season) and high-flow (wet season) periods. The aim of this was to determine which organic contaminants or groups of organic contaminants occur in the drinking water value chain (Fig. 2) and in which environmental matrix. This was followed by a decision on whether the organic contaminant should be listed on the final list of organic contaminants of concern (FLOCC), which was the outcome of this step.

\section{Study sites}

Data for assessing the occurrence of organic contaminants in the Rand Water drinking water value chain (from source to tap) were collected from the following sites:

- $\quad$ SITE 1: Vaal Dam 1 - Vaal Dam, main Rand Water source water abstraction

- SITE 2: M-Canal-Raw water canal - source water entering Zuikerbosch Drinking Water Production Plant

- SITE 3: D-DB8 - Potable water from Zuikerbosch Drinking Water Production Plant, point located $5 \mathrm{~km}$ after chlorination

- SITE 4: D-MAP_S1 - Mapleton Booster Station after chloramination

- SITE 5: S1-Tap_Vosloo - Tap water at Vosloorus Township along the S1 line from Mapleton.

\section{Field sampling}

Sample collection was conducted during the wet season (highflow period) in November/December 2007 and during the dry season (low-flow period) in April/May 2007. Sediment, water and biota (fish) were sampled from the source water environment (Vaal Dam: Site 1, C-VD1)

\section{Fish samples}

One fish species was collected from the Vaal Dam; Labeo umbratus (moggel). This is a detritivorous bottom feeder, on soft mud and detrital fish. Fish were collected by means of gill nets (40 $\mathrm{mm}$ to $150 \mathrm{~mm}$ stretch mesh size). Only females were 


\begin{tabular}{|c|c|c|c|c|c|}
\hline \multicolumn{6}{|c|}{$\begin{array}{c}\text { Table } 2 \\
\text { The preliminary list of organic contaminants of concern (PLOCC) based on the occurrence criterion } \\
\text { (evidence from the literature) }\end{array}$} \\
\hline $\begin{array}{l}\text { Naturally-occurring } \\
\text { organic contaminants } \\
\text { (18) }\end{array}$ & Industrial chemicals (63) & PPCPs (46) & Pesticides (42) & $\begin{array}{l}\text { Synthetic organic } \\
\text { polymers and residues } \\
\text { (16) }\end{array}$ & VOCs and SVOCs (66) \\
\hline $\begin{array}{l}\text { Humic acids } \\
\text { fluvic acids } \\
\text { organometallics such as } \\
\text { methyltin } \\
\text { dimethyl tin } \\
\text { MeHg } \\
\text { cyanotoxins such as anatoxin-a, } \\
\text { homoanatoxin-a, anatoxin-a(S) } \\
\text { saxitoxins } \\
\text { cylindrospermopsin } \\
\text { nodularin } \\
\text { microcystins and } \\
\text { lipo-polysaccharides } \\
\text { geosmin (trans-1,10-dimethyl- } \\
\text { trans-9-decalol) } \\
\text { 2-isobutylmethoxy-pyrazine } \\
\text { (2-IBMP) } \\
\text { 2-isopropymethoxy-pyrazine } \\
\text { (2-IPMP) } \\
\text { B-cyclocitral } \\
\text { 2-methylisorboneol (2-MIB) }\end{array}$ & 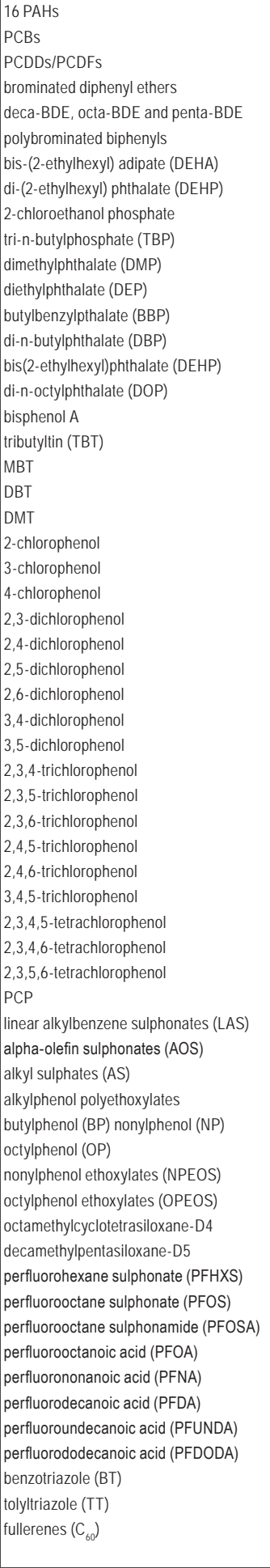 & $\begin{array}{l}\text { Heptachlor epoxide } \\
\text { endosulphan II } \\
\text { endrin aldehyde } \\
\text { endosulphan sulphate } \\
\text { endrin ketone } \\
\text { DDT and metabolites } \\
\text { hexachlorocyclohexane (HCH) } \\
\text { atrazine and metabolites } \\
\text { simazine and metabolites } \\
\text { propazine and metabolites } \\
\text { dichlorvos } \\
\text { malathion } \\
\text { glyphosate } \\
\text { omethoate } \\
\text { thionazin } \\
\text { atraton } \\
\text { terbutylazine (TBA) } \\
\text { metribuzin } \\
\text { dieldrin } \\
\text { endrin } \\
\text { methoxychlor } \\
\text { mirex } \\
\text { o,o,o-triethylphosphorothioate } \\
\text { methamidophos } \\
\text { HCB } \\
\text { heptachlor } \\
\text { aldrin } \\
\text { Y-chlordane } \\
\text { endosulphan } \\
\text { sulphotepp } \\
\text { phorate } \\
\text { dimethoate } \\
\text { disulfoton } \\
\text { parathion-methyl } \\
\text { parathion } \\
\text { isocarbophos } \\
\text { isofenphos-methyl } \\
\text { chlorpyrifos } \\
\text { dieldrin } \\
\text { azinphos-methyl } \\
\text { trichlorphos } \\
\text { famphur } \\
\text { endrin }\end{array}$ & $\begin{array}{l}\text { Heptachlor epoxide } \\
\text { endosulphan II } \\
\text { endrin aldehyde } \\
\text { endosulphan sulphate } \\
\text { endrin ketone } \\
\text { DDT and metabolites } \\
\text { hexachlorocyclohexane (HCH) } \\
\text { atrazine and metabolites } \\
\text { simazine and metabolites } \\
\text { propazine and metabolites } \\
\text { dichlorvos } \\
\text { malathion } \\
\text { glyphosate } \\
\text { omethoate } \\
\text { thionazin } \\
\text { atraton } \\
\text { terbutylazine (TBA) } \\
\text { metribuzin } \\
\text { dieldrin } \\
\text { endrin } \\
\text { methoxychlor } \\
\text { mirex } \\
\text { o,o,o-triethylphosphorothioate } \\
\text { methamidophos } \\
\text { HCB } \\
\text { heptachlor } \\
\text { aldrin } \\
\text { Y-chlordane } \\
\text { endosulphan } \\
\text { sulphotepp } \\
\text { phorate } \\
\text { dimethoate } \\
\text { disulfoton } \\
\text { parathion-methyl } \\
\text { parathion } \\
\text { isocarbophos } \\
\text { isofenphos-methyl } \\
\text { chlorpyrifos } \\
\text { dieldrin } \\
\text { azinphos-methyl } \\
\text { trichlorphos } \\
\text { famphur } \\
\text { endrin }\end{array}$ & $\begin{array}{l}\text { Polydiallyl } \\
\text { dimethyl ammonium chloride } \\
\text { (POLYDADMAC) } \\
\text { epichlorohydrin-dimethylamine } \\
\text { (epi-DMA) } \\
\text { dimethylamine } \\
\text { allylchloride } \\
\text { diallylether } \\
\text { 1,3-dichloro-2-propanol } \\
\text { 2,3-dichloro-1-propanol } \\
\text { 1,3-bis(dimethylamino)-2-propanol } \\
\text { 2-hydroxy-3-dimethylamino } \\
\text { propylchloride } \\
\text { 3-chloro-1,2-propanediol } \\
\text { epichlorohydrin } \\
\text { glycidol } \\
\text { 5-hexanal } \\
\text { anionic polyacrylamide (PA) } \\
\text { cationic polydimethyl diallyl } \\
\text { ammonium chloride } \\
\text { non-ionic polyacrylamide }\end{array}$ & 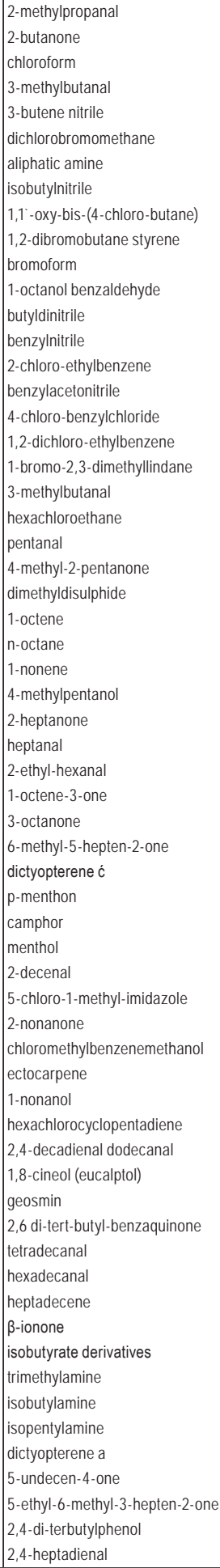 \\
\hline
\end{tabular}

used for the study due to cost and the fact that gonads (eggs) of females are known to be suitable tissue for the accumulation of organics due to their fatty nature.

After capture the fish were transferred to a holding tank filled continuously with water from Site 1 . Before dissecting the fish, the fish were rinsed in water from the body surface. The fish were then killed by a hard blow on the head. Dissection was done on polythene dissection boards using high quality stainless steel dissection tools. Muscle tissue (skinless), gonads, liver and fat tissue were separated and packaged separately 


\begin{tabular}{|c|c|c|c|c|c|c|c|c|c|c|c|}
\hline \multicolumn{12}{|c|}{$\begin{array}{l}\text { Table } 3 \\
\begin{array}{c}\text { An example of the characterisation of the preliminary list of organic contaminants of concern (PLOCC) } \\
\text { as per screening criteria; Step III of the protocol }\end{array}\end{array}$} \\
\hline \multirow[b]{2}{*}{ 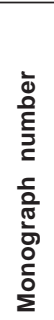 } & \multirow[t]{2}{*}{ Parameter } & \multicolumn{9}{|c|}{ Human health concern } & \multirow[t]{2}{*}{ Remarks } \\
\hline & & 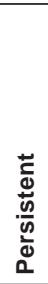 & 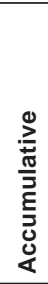 & 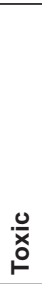 & 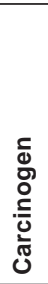 & 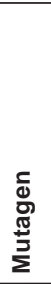 & 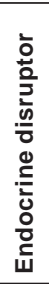 & 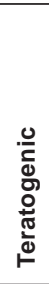 & 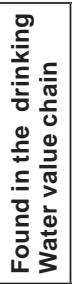 & 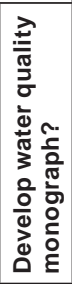 & \\
\hline \multicolumn{12}{|c|}{ A. INDUSTRIAL CHEMICALS } \\
\hline A1 & Benzene & $\mathrm{Y}$ & $\mathrm{Y}$ & $\mathrm{Y}$ & $\mathrm{Y}$ & $\mathrm{Y}$ & - & $\mathrm{Y}$ & $\mathrm{Y}$ & $\mathrm{Y}$ & Also causes taste and odour problems \\
\hline- & Chlorobenzene & $\mathrm{N}$ & $\mathrm{N}$ & $\mathrm{Y}$ & $\mathrm{Y}$ & $\mathrm{N}$ & $\mathrm{N}$ & $\mathrm{N}$ & $\mathrm{Y}$ & $\mathrm{N}$ & Liver or kidney problems \\
\hline- & 1,2-dichlorobenzene & $\mathrm{N}$ & $\mathrm{N}$ & $\mathrm{Y}$ & $\mathrm{Y}$ & $\mathrm{Y}$ & $\mathrm{N}$ & $\mathrm{Y}$ & $\mathrm{Y}$ & $\mathrm{N}$ & Liver, kidney or circulatory system problems \\
\hline- & 1,2,4-trichlorobenzene & $\mathrm{N}$ & $\mathrm{N}$ & $\mathrm{Y}$ & - & - & - & - & $\mathrm{Y}$ & $\mathrm{N}$ & Changes in adrenal glands \\
\hline- & 1,4-dichlorobenzene & $\mathrm{N}$ & $\mathrm{N}$ & $\mathrm{Y}$ & - & - & - & - & $\mathrm{Y}$ & $\mathrm{N}$ & Yellow atrophy and cirrhosis of the liver \\
\hline- & Pentachlorobenzene & $\mathrm{N}$ & $\mathrm{N}$ & $\mathrm{Y}$ & - & - & - & - & $\mathrm{Y}$ & $\mathrm{N}$ & Liver and kidney toxicity \\
\hline- & Trichlorobenzenes (total) & $\mathrm{N}$ & $\mathrm{N}$ & $\mathrm{Y}$ & - & - & - & - & $\mathrm{Y}$ & $\mathrm{N}$ & See individual CBs \\
\hline- & $\begin{array}{l}\text { Polynuclear aromatic } \\
\text { hydrocarbons }\end{array}$ & $\mathrm{Y}$ & $\mathrm{Y}$ & $\mathrm{Y}$ & $\mathrm{Y}$ & - & $\mathrm{Y}$ & - & $\mathrm{Y}$ & $\mathrm{N}$ & $\begin{array}{l}\text { Exert toxic effects through the aryl hydrogen } \\
\text { receptor mediated mechanism }\end{array}$ \\
\hline A2 & Benzo [a] pyrene & $\mathrm{Y}$ & $\mathrm{Y}$ & $\mathrm{Y}$ & $\mathrm{Y}$ & $\mathrm{Y}$ & $\mathrm{Y}$ & $\mathrm{Y}$ & $\mathrm{Y}$ & $\mathrm{Y}$ & Most toxic polynuclear aromatic hydrocarbon \\
\hline
\end{tabular}

according to composite sample requirements. Three composite samples of each fish tissue were prepared to allow for replicate analysis. Composite samples were packaged individually in extra heavy aluminium foil, placed in a waterproof plastic bag and, depending on the transportation time, kept on wet ice or frozen on dry ice as per the recommendations of Du Preez et al. (2003). On arrival at the laboratory, the samples were kept frozen in a freezer until analysis commenced.

\section{Water samples}

Samples were collected in triplicate from the 5 locations described above. The sample bottles were selected depending on the type of analysis. For example, for pesticide residue analysis, $2.5 \ell$ amber bottles were used. Water samples for volatile organic compounds (VOCs), semi-volatile organic compounds (SVOCs) and bisphenol A were collected in $1 \ell$ glass bottles with Teflon-lined caps. The samples were delivered to the respective laboratories and kept cool at $4^{\circ} \mathrm{C}$ until analysed.

\section{Sediment samples}

Surface sediment from the Vaal Dam was collected using the Edman grab methodology. The sediment was collected in 125 $\mathrm{m} \ell$ wide mouth glass jars with a Teflon-lined seal. The samples were collected in triplicate and delivered to the respective laboratories. Samples were kept cool at $4^{\circ} \mathrm{C}$ until analysed.

\section{Laboratory procedures}

The following procedures were used for the assessment of organic contaminants in fish, sediment and water from the above sample points. Two approaches were used, namely target analysis and multi-residue analysis. For maximum benefit, the organic contaminants on the PLOCC were arranged into functional groups. This made it possible for most of them to be screened using the multi-residue analysis approach. In the multi-residue approach, a single extraction method was used to determine the most commonly encountered pesticides, such as organochlorine pesticides (OCPs), organophosphorus pesticides (OPs), polychlorinated biphenyls (PCBs) and pyrethroid groups of pesticides, using gas chromatography with an electron capture detector (GC-ECD) or flame photometry detector (GC-FPD), depending on the properties of the compounds. If pesticides were detected, the presence of the particular compound was confirmed using GC-MS. It is important to note that not all pesticides would be detected using the multi-residue approach due to the nature and physical properties of certain compounds. These could only be detected and quantified using the target analysis approach.

In the target analysis approach, a method unique to a specific compound or group of compounds was used. For example, semi-volatile organics in both water and sediment were determined using GC-MS Method AM 186 based on US EPA 8270 (USEPA, 2007). Benzene, toluene, ethylbenzene and xylene isomers, commonly called the BTEX group, were determined in water samples using the purge-and-trap GC-MS Method GC 050, based on US EPA 8260 (USEPA, 1996a). The method is SANAS-accredited for target compound analysis. This analysis was performed by the CSIR Organic Analysis Laboratory.

\section{Assessment of organic contaminants in fish tissue}

On analysis, the samples were passed through a meat mincer. Single determinations on representative portions of the wellmixed samples were carried out using SABS in-house Method No. 021/2001 'Multi-residue method for the determination of organochlorine and synthetic pyrethroid pesticide residues in animal tissue' (SABS, 2001). This method was used to determine the concentration levels of organic contaminants. Recovery determinations were carried out by adding known amounts of the relevant pesticides to portions of a laboratory control sample and analysing these concurrently with the actual samples. Organochlorine pesticides, organophosphorus pesticides, synthetic pyrethroids and PCB congeners were determined using this method for each fish tissue. Triplicate analysis was done for each composite sample.

\section{Assessment of organic contaminants in sediment and water samples}

Organochlorine pesticides, organophosphorus pesticides, 
synthetic pyrethroids, PCB congeners, triazines, chloracetamides were analysed using the method as described in the Official Methods of Analysis of AOAC International: $16^{\text {th }}$ Edition, Volume 1 (AOAC International, 1995). Phenoxyacetic acids, 2,4-D and MCPA were analysed using SABS in-house Method No. 018/2000 'Determination of 2,4-D residues in various citrus and relevant matrices' (SABS, 2000). To analyse for dichlorprop, Method CFP1 1991 for determining residues of dichlorprop in citrus fruits was used. The EPA Method 625 Base/Neutrals and Acids (USEPA, 1984) were used for extraction in both cases. Carbamate pesticides (aldicarb, aldicarb sulphone, aldicarb sulphoxide, carbaryl, carbofuran, carbosufan and propoxur) were analysed using Method No. AM127 and Official Methods of Analysis of AOAC International were used for extraction.

For the determination of selected volatile compounds on the PLOCC in sediment samples, such as benzene, toluene, ethylbenzene, m,p-xylene and o-xylene (BTEX group) an inhouse Headspace GC-MS Method AM191, based on USEPA methods 5021 (USEPA, 1996b) and 8260 (USEPA, 1996a) was used. This is a target compound analysis. Bisphenol A was determined using a CSIR in-house GC-MS method. Semivolatile organic compounds were determined using an in-house GC-MS method, AM 186 (based on USEPA method 8270) (USEPA, 2007).

\section{Statistical procedures and data processing}

The objective of data analysis was to find out whether or not there was a significant difference among the 5 sites, among the 3 matrices per site for the first 2 sample sites, among the 11 groups per matrix, and to assess the effect of samples for significance. This is a typical generalised linear modelling procedure in statistics. The statistical model used was the univariate repeated measures analysis of variance (ANOVA). The model was univariate as there was only one outcome variable of interest (the level of concentration of each organic compound obtained from each sample). Data entry and analysis was done using the statistical package STATA Version 10. Generalised linear models were used for extensive data analysis. Standard diagnostic procedures for generalised linear models were used to assess the adequacy of the fitted model.

\section{The validation of the FLOCC by drinking water industry experts}

The main aim of this step was to confirm the need to prioritise the organic contaminant(s) or group of organic contaminants for monitoring in the drinking water value chain and to confirm the final list of organic contaminants of concern (FLOCC). The preliminary list of organic contaminants of concern (PLOCC; Table 2) obtained from Step III was also presented to the group of experts from the drinking water industry and relevant stakeholders for validation. The workshop was informed of the results of the assessment of PLOCC organic contaminants in the drinking water value chain. At this workshop it was agreed that most of the organic contaminants on the PLOCC were already in the WHO drinking water quality guideline document (WHO, 2004), which receives extensive internationa rolling revision. Factors such as relevance to the South African drinking water industry, potential for being detected in any of the critical control points along the drinking water value chain, evidence of adverse human health effects, previous regulation, such as the Stockholm Convention 'dirty dozen' and being registered for use in drinking water treatment, were considered during the exercise. Those organic contaminants that were detected in any matrix of interest during the assessment for occurrence in the drinking water value chain were moved directly onto the FLOCC (Table 4).

The following aspects were also considered in identifying compounds for the FLOCC. It was agreed that:

- Benzo[a] pyrene is the most toxic of all the 16 recognised PAHs, hence it will not be necessary to analyse for all 16 but to use $\mathrm{BaP}$ as an indicator for assessing contamination by PAHs.

- Benzene is a known human carcinogen. It is already being analysed for in the BTEX group for protection against organoleptic properties such as taste and odour and to safeguard against consumer complaints. If benzene is appropriately controlled in the drinking water value chain, chlorinated benzenes will be minimised, especially those forming after chlorination.

- Glycol ethers have been associated with taste and odours in surface waters. It was decided to adopt the group as being of concern.

- Plasticisers such as bisphenol A, di-n-butylphthalate, and di-(2-ethylhexyl)phthalate, and detergent metabolites octylphenol and nonylphenol, are known for their oestrogen-mimicking effects as evidenced from previous local research.

- The 'dirty dozen' list on the PLOCC was adopted as the list of organic contaminants of concern. Hence it was automatically transferred on the FLOCC.

- It was decided to move all organochlorine pesticides with enough information on occurrence and potential adverse health effects, as shown by the literature and the assessment exercise, onto the FLOCC.

- Some parent organic contaminants such as hexachlorocyclohexane $(\mathrm{HCH})$ have no significance to drinking water but have isomers, such as $\beta-\mathrm{HCH}, \delta-\mathrm{HCH}, \gamma-\mathrm{HCH}$, which have been found to cause endocrine disruption effects and liver tumours and are persistent in the environment. The same applies to triazine herbicides such as atrazine and simazine which degrade into more stable metabolites of greater human health concern.

- Benzene and its chlorinated products were moved onto the FLOCC due to taste and odour concerns.

- Synthetic polymer residues, especially those that are known be in use in some water treatment plants, were also moved onto the FLOCC.

- Disinfection by-products which have been positively identified during the assessment in the drinking water value chain and those that are currently regulated were also moved onto the FLOCC.

- Polychlorinated biphenyls are currently being regulated in South Africa under the Africa Stockpiles Project. It was agreed that the group consists of a number of congeners. Only those contaminants that have been detected and whose standards are available were added onto the FLOCC. Another proposal was the analysis of PCB-153 as an indicator of the group since standards for this congener are available.

- Pharmaceuticals and personal care products which were detected in aquatic environments were moved onto the FLOCC due to their perceived risks.

From the preceding step, it was evident that some of the organic contaminants on the PLOCC were excluded from the process. One hundred and twenty (120) organic contaminants, 
including some metabolites where relevant, were identified for the FLOCC (Table 4).

\section{Establishment of technical capability for the removal of organic contaminants through conventional water treatment, and recommendations for the implementation of the FLOCC}

The assumptions influencing this step were that rural community-based water utilities, and some urban ones, especially in developing countries, still have poor infrastructure that does not meet the current challenges for organic contaminant removal, and some organic contaminants can escape the treatment process and be a potential risk to the consumer. Based on these assumptions it was recommended that rural communitybased utilities and those that do not have the capacity to remove selected groups of organic contaminants should test for organic contaminants in their drinking water value chains. In this case, those laboratories that are accredited for organic analysis or with the capability for analysis, such as in universities and similar research organisations, can be used by the water utility to analyse its water samples. The organic contaminants positively identified in such programmes will be added to the preliminary priority list of organic contaminants (PPLOC). In South Africa, such evidence could be gathered from national published documents such as Water Research Commission (WRC) project reports and articles published in Water SA.

\section{Prioritisation of the organic contaminants on the final list of organic contaminants (FLOCC)}

The 120 organic contaminants on the FLOCC list were prioritised using the criteria presented in Step VI of the protocol. It was agreed that the highest-priority chemicals are those that have been shown to cause human health effects as a consequence of exposure through drinking water. It was decided that the highpriority chemical list can be modified if those chemicals are found not to be present, but a chemical not found in an initial investigation should not be forgotten. As a result, the prioritisation criteria were applied to the FLOCC but observations made in other steps were used to take a final decision on whether to eliminate an organic contaminant from the preliminary priority list of organic contaminants, or to add it to the list.

\section{Occurrence criterion}

Evidence for occurrence of the organic contaminant was collected in 4 tiers in preceding steps, i.e., from the literature, in the water quality monograph development process, using expert knowledge and judgement, and testing for the occurrence of organic contaminants in the drinking water value chain. This was followed by a decision on whether the organic contaminant was positively identified or not in the drinking water value chain. The responses are indicated as shown in Table 5 under the column 'Found in the drinking water value chain?'. The response is indicated qualitatively in the form of ' $\mathrm{Y}$ ' for 'yes' or ' $\mathrm{N}$ ' for 'no'.

\section{Adverse human health criterion}

The information gathered from the literature review and water quality monographs was used at this stage as it would already be available in Table 5. This information and the information obtained from the preceding section is combined to assist in prioritising the organic contaminants in 4 groups. At this stage, the prioritisation approach identifies:

\begin{tabular}{|c|c|c|c|c|c|}
\hline \multicolumn{6}{|c|}{$\begin{array}{c}\text { Table } 4 \\
\text { The final list of organic contaminants of concern (FLOCC) }\end{array}$} \\
\hline Industrial chemicals (31) & Pesticides (32) & \begin{tabular}{|l|} 
Disinfection by- \\
products (DBPs) \\
(18)
\end{tabular} & Polymer residues (13) & Cyanotoxins (10) & PPCPs (26) \\
\hline $\begin{array}{l}\text { Benzene } \\
\text { Chlorobenzene } \\
\text { 1,2-Dichlorobenzene } \\
\text { 1,2,4-Trichlorobenzene } \\
\text { 1,4-Dichlorobenzene } \\
\text { Pentachlorobenzene } \\
\text { 2-Chlorophenol } \\
\text { 2,4-Dichlorophenol } \\
\text { 2,4,6-Dichlorophenol } \\
\text { Pentachlorophenol } \\
\text { Di-2-(ethylhexyl)phthalate } \\
\text { Di-n-butylphthalate } \\
\text { Di-2-ethylhexyladipate (DEHA) } \\
\text { 2,3,7,8-Tetrachlorodiphenyldioxin } \\
\text { Nitrilotriacetic acid (NTA) } \\
\text { Benzo[a]pyrene } \\
\text { Bisphenol A } \\
\text { Ethylbenzene } \\
\text { Ethylene glycol monethylether } \\
\text { Ethylene glycol methyl ether acetate } \\
\text { Ethylene glycol monobutyl ether } \\
\text { Acetate } \\
\text { p-Octylphenol } \\
\text { p-Nonylphenol } \\
\text { Polychlorinated biphenyls (Aroclor 1016, } \\
\text { Aroclor 1254, Aroclor 1260) } \\
\text { Toluene } \\
\text { Xylene isomers } \\
\text { Dibutyltin } \\
\text { Dimethyltin } \\
\text { Tributyltin }\end{array}$ & $\begin{array}{l}\text { 2,4-Dichlorophenoxyacetic } \\
\text { acid [2,4-D] } \\
\text { Fenoprop } \\
\text { MCPA } \\
\text { Aldrin* } \\
\text { Atrazine and metabolites* } \\
\text { Dieldrin* } \\
\text { Chlorpyrifos } \\
\text { Cyhexatin } \\
\text { DDT* } \\
\text { DDD } \\
\text { DDE } \\
\text { Diquat } \\
\text { Endosulphan } \\
\text { Endosulphan sulphate } \\
\text { B-Endosulphan } \\
\text { Endrin } \\
\text { Heptachlor* } \\
\text { Heptachlor epoxide } \\
\text { Lindane } \\
\text { Methoxychlor } \\
\text { Paraquat } \\
\text { Simazine* } \\
\text { Terbutylazine* } \\
\text { Acetochlor } \\
\text { Metolachlor* } \\
\text { Aldicarb* } \\
\text { Deltamethrin* } \\
\text { Vinclozolin } \\
\text { Cyanazine } \\
\text { Hexachlorobenzene (HCB) } \\
\text { HCH isomers } \\
\text { Cypermethrin }\end{array}$ & $\begin{array}{l}\text { Chloroform* } \\
\text { Bromodichloromethane* } \\
\text { Dibromochloromethane* } \\
\text { Formaldehyde } \\
\text { Trichloroacetaldehyde } \\
\text { Monochloroacetic acid } \\
\text { Trichloroacetic acid } \\
\text { Dichloroacetic acid } \\
\text { Bromoacetic acid } \\
\text { Dibromoacetic acid } \\
\text { Bromochloroacetic acid } \\
\text { Dichloroacetonitrile } \\
\text { Trichloroacetonitrile } \\
\text { Bromoacetonitrile } \\
\text { Chloroacetonitrile } \\
\text { Bromoacetonitrile } \\
\text { Dibromoacetonitrile } \\
\text { Nitrosodimethylamine } \\
\text { THMs }\end{array}$ & $\begin{array}{l}\text { Acrylamide } \\
\text { Epichlorohydrin } \\
\text { Diallyldimethylammonium chloride } \\
\text { Dimethylamine } \\
\text { Allyl chloride } \\
\text { Diallyl chloride } \\
\text { 5-Hexanal glycidol } \\
\text { 1,3-Dichloro-2-propanol } \\
\text { 2,3-Dichloro-1-propanol } \\
\text { 3-Chloro-1,2-propanediol } \\
\text { 2-Hydroxy-3-dimethylaminopropyl chloride } \\
\text { 1,3-Bis (dimethylamino)-2-propanol }\end{array}$ & $\begin{array}{l}\text { Geosmin*; } \\
\text { 2-MIB* } \\
\text { Anatoxin-a } \\
\text { Homoanatoxin-a } \\
\text { Anatoxin-a(S) } \\
\text { Microcystins } \\
\text { Saxtoxins } \\
\text { Cylindrospermopsin } \\
\text { Nodularin } \\
\text { 及-Methylaminoalanine }\end{array}$ & \begin{tabular}{|l} 
Triclosan \\
Trimethropin \\
Erythromycine \\
Lincomycin \\
Sulphamethaxole \\
Amoxycillin \\
Ibuprofen \\
Diclofenac \\
Fenoprofen \\
Naproxen \\
Acetaminophen \\
Acetylsalicylic acid \\
Fluoxetine \\
Paracetamol \\
Clofibric acid \\
Bezafibrate \\
Fenofibric acid \\
Carbamazepine \\
Cotinine \\
B-Coprostanol \\
Primidone \\
Gemifibrozil \\
17ß-Estradiol \\
Estriol \\
Estrone \\
17a-Ethinylestradiol
\end{tabular} \\
\hline
\end{tabular}

*Detected in the Rand Water drinking water value chain 


\begin{tabular}{|c|c|c|c|c|c|c|c|c|c|c|c|c|c|c|c|}
\hline \multirow[b]{3}{*}{ 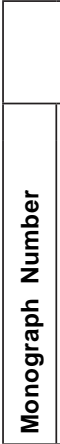 } & \multicolumn{15}{|c|}{$\begin{array}{c}\text { Table } 5 \\
\text { The Preliminary Priority List of Organic Contaminants (PPLOC) for monitoring } \\
\text { in the drinking water value chain (example - details in Ncube, 2009) }\end{array}$} \\
\hline & \multirow[t]{2}{*}{ Parameter } & \multirow[t]{2}{*}{ Units } & \multirow[t]{2}{*}{ Standard/Guideline } & \multicolumn{11}{|c|}{ Human health concern } & \multirow[t]{2}{*}{ Remarks } \\
\hline & & & & 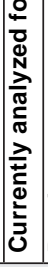 & 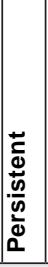 & 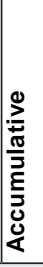 &.$\stackrel{0}{x}$ & & & & כל & 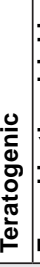 & 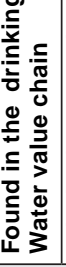 & 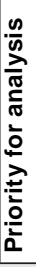 & \\
\hline \multicolumn{16}{|c|}{ A. INDUSTRIAL CHEMICALS } \\
\hline A1 & Benzene & $\mu \mathrm{g} / \ell$ & $\begin{array}{l}\text { 10(WHO), 5(USEPA), } \\
\text { 10(NZ), 1(AU) }\end{array}$ & $\mathrm{Y}$ & $\mathrm{Y}$ & $\mathrm{Y}$ & $\mathrm{Y}$ & $Y$ & $Y \mathrm{Y}$ & $Y$ & - & $\mathrm{Y}$ & $\mathrm{Y}$ & S & Taste and odour problems \\
\hline A2 & Benz [a] pyrene & $\mu \mathrm{g} / \ell$ & $\begin{array}{l}\text { 0.2(US), 0.7(WHO), } 0.7 \text { (NZ), } \\
0.01(\mathrm{EU}), 0.01(\mathrm{AU})\end{array}$ & $\mathrm{Y}$ & $\mathrm{Y}$ & $\mathrm{Y}$ & $\mathrm{Y}$ & $Y$ & $T$ & 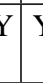 & $\mathrm{Y}$ & $\mathrm{Y}$ & $\mathrm{Y}$ & $\mathrm{S}$ & $\begin{array}{l}\text { Most toxic polynuclear aro- } \\
\text { matic hydrocarbon }\end{array}$ \\
\hline B1 & $\begin{array}{l}\text { 2,4 Dichlorophenoxy- } \\
\text { acetic acid }\end{array}$ & $\mu \mathrm{g} / \ell$ & $\begin{array}{l}\text { 70(USEPA), 30(WHO), } \\
40(\mathrm{NZ})\end{array}$ & $\mathrm{Y}$ & $\mathrm{N}$ & $\mathrm{N}$ & $\bar{Y}$ & $Y$ & $Y \mathrm{~N}$ & N & $\mathrm{Y}$ & $\mathrm{N}$ & $\mathrm{Y}$ & $S$ & Currently regulated herbicide \\
\hline B2 & Aldrin & $\mu \mathrm{g} / \ell$ & \begin{tabular}{|l|} 
0.03(WHO), 0.04(NZ), \\
0.03(USEPA), 0.03(EU), \\
0.3(AU),0.7(Can)
\end{tabular} & $\mathrm{Y}$ & $\mathrm{Y}$ & $\mathrm{N}$ & $\mathrm{Y}$ & $Y$ & $\overline{Y Y}$ & \begin{tabular}{l|l}
$Y$ & $S$
\end{tabular} & Su & $\mathrm{N}$ & $\mathrm{Y}$ & $S$ & $\begin{array}{l}\text { Immediately converted } \\
\text { to dieldrin in the aqueous } \\
\text { environment }\end{array}$ \\
\hline- & Pendimethalin & $\mu \mathrm{g} / \ell$ & 20(WHO), 20 (NZ), 300(AU) & $\mathrm{N}$ & $\mathrm{Y}$ & $\mathrm{Y}$ & $\mathrm{Y}$ & - & -1 & $\mathrm{~N}$ & - & $\mathrm{N}$ & $\mathrm{N}$ & $\mathrm{L}$ & Liver toxicity \\
\hline- & Linuron(herbicide) & $\mu \mathrm{g} / \ell$ & - & $\mathrm{N}$ & $\mathrm{N}$ & - & $\mathrm{Y}$ & $Y$ & $\bar{Y} \mathrm{I}$ & $\mathrm{N}$ & $\mathrm{Y}$ & $\mathrm{N}$ & - & $\mathrm{L}$ & Testicular hyperplasia \\
\hline E5 & Allyl chloride & $\mu \mathrm{g} / \ell$ & - & $\mathrm{N}$ & $\mathrm{N}$ & $\mathrm{N}$ & $\bar{Y}$ & $Y$ & $\overline{Y I}$ & Y & - & - & N/A & $\mathrm{M}$ & No criteria for regulation \\
\hline E6 & Diallyl ether & $\mu \mathrm{g} / \ell$ & - & $\mathrm{N}$ & $\mathrm{N}$ & $\mathrm{N}$ & $\mathrm{Y}$ & $Y$ & $Y$ & - & - & - & N/A & $\mathrm{M}$ & $\begin{array}{l}\text { VOC, no drinking water } \\
\text { criteria }\end{array}$ \\
\hline- & Pentachlorobenzene & $\mu \mathrm{g} / \ell$ & - & $?$ & $\mathrm{~N}$ & $\mathrm{~N}$ & Y & - & 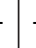 & - & - & - & N/A & $\mathrm{S}$ & Liver and kidney toxicity \\
\hline- & $\begin{array}{l}\text { Trichlorobenzenes } \\
\text { (Total) }\end{array}$ & $\mu \mathrm{g} / \ell$ & $30(\mathrm{AU})$ & $\mathrm{Y}$ & $\mathrm{N}$ & $\mathrm{N}$ & $\mathrm{Y}$ & - & 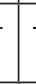 & - & - & - & N/A & $\mathrm{S}$ & See individual CBs \\
\hline- & $\begin{array}{l}\text { Polynuclear aromatic } \\
\text { hydrocarbons }\end{array}$ & $\mu \mathrm{g} / \ell$ & $0.10(\mathrm{EU})$ & $\mathrm{Y}$ & $\mathrm{Y}$ & $\mathrm{Y}$ & $Y$ & $Y$ & $Y$ & - & $\mathrm{Y}$ & - & N/A & $\mathrm{S}$ & $\begin{array}{l}\text { Toxic effects, aryl hydrogen } \\
\text { receptor mechanism }\end{array}$ \\
\hline
\end{tabular}

Notes: Y-'Yes', N-'No', Su-'Suspected', S-Analysis in the short term (1-2 years), M-Analysis in the medium term (3-5years), L-Analysis in the long term (5-10 years), N/A-Not assessed

- Contaminants that are demonstrated to have relatively high toxicity with high potential to occur in the drinking water value chain (Table 5)

- Contaminants that are demonstrated to have relatively high toxicity with minimal actual or potential occurrence in the drinking water value chain (Table 5)

- Contaminants that are demonstrated to have high potential to occur in the drinking water value chain with relatively moderate toxicity (Table 5)

- Contaminants that are demonstrated to have minimal potential to occur in the drinking water value chain with relatively moderate toxicity (Table 5)

The approach considers and uses as many of the available types of health effects and occurrence data identified in the data source evaluation as practical (Table 5).

\section{Other criteria}

The above list was further prioritised using the drinking water industry perspective and requirements. It was advisable that local conditions should define this process. The criteria covered aspects such as:

- The availability of standards/guidelines for regulation

- Potential to cause water quality problems

- Potential to stimulate customer perception of risk
- Removal efficiency and availability of expertise and capacity for analysis

Based on these criteria, a semi-quantitative approach was used and 3 priority lists of organic contaminants were identified (Table 5). The organic contaminants were prioritised into short-term (S), medium-term (M) and long-term (L) priority for analysis in the drinking water value chain. Those organic contaminants placed on the short-term priority list were adopted for immediate routine monitoring in the drinking water value chain.

- Short-term (S) Organics falling within this category are listed in Table 5 and are selected based on the following characteristics: the wide range of potential human health concerns via the drinking water ingestion route; the substance is known to cause water quality problems in the drinking water value chain such as the cause of offensive tastes and odours; evidence that the occurrence of a substance or group increases customers' perception of risk; enough resources in place to support ease of monitoring; poor removal efficiency using conventional water treatment methods; availability of drinking water standards/ guidelines to enable regulation and proof of occurrence in the drinking water value chain, especially those contaminants formed during drinking water treatment, distribution, 


\begin{tabular}{|c|c|c|c|c|c|}
\hline \multicolumn{6}{|c|}{$\begin{array}{c}\text { Table } 6 \\
\text { The priority list of organic contaminants for monitoring in the drinking water value chain }\end{array}$} \\
\hline Industrial chemicals (29) & Pesticides (37) & $\begin{array}{l}\text { Disinfection by- } \\
\text { products (DBPs) } \\
(13)\end{array}$ & Polymer residues (7) & $\begin{array}{l}\text { Cyanotoxins } \\
(9)\end{array}$ & PPCPs (5) \\
\hline \begin{tabular}{|l} 
Benzene \\
Chlorobenzene \\
1,2-Dichlorobenzene \\
1,2,4-Trichlorobenzene \\
1,4-Dichlorobenzene \\
Pentachlorobenzene \\
2-Chlorophenol \\
2,4-Dichlorophenol \\
2,4,6-Dichlorophenol \\
Pentachlorophenol \\
Di-2-(ethylhexyl)phthalate \\
Di-n-butylphthalate \\
Di-2-(ethylhexyladipate (DEHA) \\
2,3,7,8-Tetrachlorodiphenyldioxin \\
Nitrilotriacetic acid (NTA) \\
Benzo[a]pyrene \\
Bisphenol A \\
Ethylbenzene \\
p-Octylphenol \\
p-Nonylphenol \\
Polychlorinated biphenyls \\
(Aroclor 1016; Aroclor 1248; \\
Aroclor 1254; Aroclor 1260) \\
Toluene \\
Xylene isomers \\
Dibutyltin \\
Dimethyltin \\
Tributyltin
\end{tabular} & 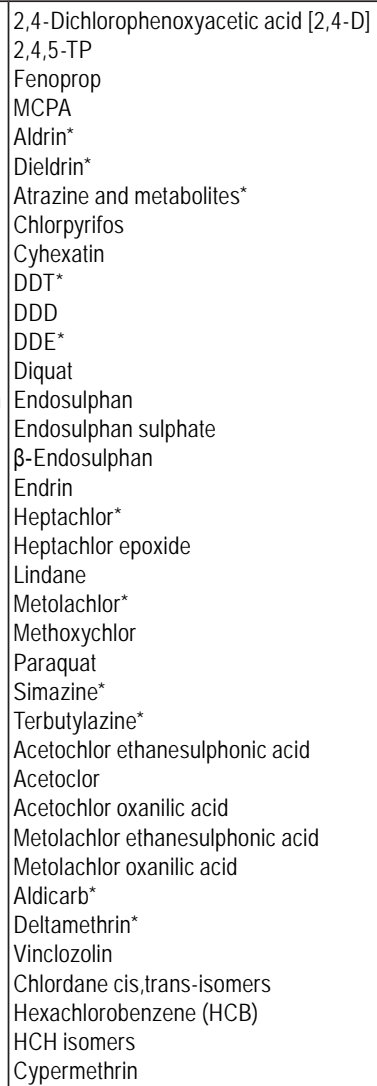 & $\begin{array}{l}\text { Chloroform* } \\
\text { Bromodichloromethane* } \\
\text { Dibromochloromethane* } \\
\text { Formaldehyde } \\
\text { Trichloroacetaldehyde } \\
\text { Monochloroacetic acid } \\
\text { Trichloroacetic acid } \\
\text { Dichloroacetic acid } \\
\text { Bromoacetic acid } \\
\text { Dibromoacetic acid } \\
\text { Bromochloroacetic acid } \\
\text { Nitrosodimethylamine } \\
\text { THMs }^{*}\end{array}$ & $\begin{array}{l}\text { Acrylamide } \\
\text { Epichlorohydrin } \\
\text { Diallyldimethylammonium chloride } \\
\text { Dimethylamine } \\
\text { 1,3-Dichloro-2-propanol } \\
\text { 2,3-Dichloro-1-propanol } \\
\text { 3-Chloro-1,2-propanediol }\end{array}$ & $\begin{array}{l}\text { Geosmin* } \\
\text { 2-MIB* } \\
\text { Anatoxin-a } \\
\text { Homoanatoxin-a } \\
\text { Anatoxin-a(S) } \\
\text { Microcystin-LR } \\
\text { Saxtoxin } \\
\text { Cylindrospermopsin } \\
\text { Nodularin }\end{array}$ & \begin{tabular}{|l|}
$17 \beta$-Estradiol \\
Estriol \\
Estrone \\
$17 a-$ Ethinylestradiol \\
Diethylstilbestrol (DES)
\end{tabular} \\
\hline
\end{tabular}

storage and use. At least four or more aspects must be satisfied of which the potential to cause adverse health effects and water quality problems must be part of them.

- Medium-term (M) substances falling within this category are listed in Table 5. Organic constituents in this category are selected based on the following characteristics: The wide range of potential human health concerns via the drinking water ingestion route; ability to cause water quality problems in the drinking water value chain such as the cause of offensive tastes and odours; evidence that the occurrence of a substance or group increases customers' perception of risk; no resources in place to support ease of monitoring; moderate removal efficiency using conventional water treatment methods; non-availability of drinking water standards/guidelines to enable regulation; proof of occurrence in the drinking water value chain especially those contaminants formed during drinking water treatment, distribution, storage and use.

- Long-term $(\boldsymbol{L})$ substances falling within this category are listed in Table 6. Organic constituents in this category are selected based on the following characteristics: insufficient information on human health concerns via the drinking water ingestion route; insufficient information on the impact of the organic contaminant on drinking water quality; no evidence that the occurrence of a substance or group increases customers' perception of risk; no resources in place to support ease of monitoring; removed from drinking water using conventional water treatment methods; non-availability of drinking water standards/guidelines to enable regulation; proof of occurrence in the drinking water value chain especially those contaminants formed during drinking water treatment, distribution, storage and use. On completion of the preceding steps, 3 categories of organic constituents of importance to the water utility and its customers were established (Table 5). The outcome of this step was a preliminary priority list of organic contaminants (PPLOC) for monitoring in the drinking water value chain (Table 5). This list was finalised after consulting with the relevant experts at a workshop.

\section{Validation of the priority list of organic contaminants by drinking water industry experts and relevant stakeholders}

The preliminary priority list of organic contaminants obtained from Step VI (Table 5) was presented to a group of experts from the drinking water industry and relevant stakeholders for validation. At this workshop, industry-specific criteria and analytical challenges were identified as other aspects affecting organic analysis by water utilities. The preliminary priority list of organic contaminants (PPLOC; Table 5) was assessed and the priority list of organic contaminants finalised. All contaminants with priority ' $\mathrm{S}$ ' for analysis were moved onto the priority list of organic contaminants (Table 6). Benchmarking with other national and international bodies such as the WHO, USEPA, OECD and EU was done at this stage. However, local conditions and relevancy were given more emphasis. The outcome of this step was a list of 100 priority organic 
contaminants for monitoring in the drinking water value chain. This includes key metabolites and isomers for organochlorine pesticides such as DDT, chlordane, hexachlorocyclohexane $(\mathrm{HCH})$, acetamide herbicides such as metolachlor and acetoclor and metabolites of S-triazine herbicides.

\section{Results and discussion}

The implementation of the protocol began with the identification of potential drinking water organic contaminants prior to any attempts to screen or sort them. These covered a range of organic contaminants that the consumers can be exposed to via the drinking water ingestion route, dermal contact during recreational activities including other relevant water uses and the inhalation route. During the validation of the 'pool of organic contaminants', workshop attendees felt that most organic contaminants were already represented in the WHO guidelines for drinking water quality document, (3rd edition) published in 2004. It was therefore agreed that the list will form part of the working document to be used in Step II of the protocol. The reasons given were the fact that the document is produced by experts across the world and undergoes a rolling revision to update the information. This emphasized the role of expert judgment in decision-making. In this study, the 'occurrence criteria', evidence of occurrence in environmental samples collected along the drinking water value chain, and expert judgment were considered adequate for an organic contaminant to be placed on a 'priority list of organic contaminants for monitoring in the drinking water value chain'. In the event that the occurrence criteria, the PBT criteria and information gathered during the water quality monograph development were not enough to assist the decision-making process on whether to place the organic contaminants on the list of organic contaminants of concern (Table 3), other criteria relevant to the drinking water industry were used.

The major challenge was the limited information on some organic contaminants to allow for decision making based on the occurrence and human health effects criteria. This was true for compounds such as synthetic organic polymer residues; allyl chloride, diallyl ether, 5-hexanal and glycidol, identified benzotriazoles, some plasticisers such as 2-chloroethanol phosphate and tri-n-butylphosphate, some pesticides such as 3,4-dichloroaniline, 3,3',4,4'-tetrachloroazobenzene, disulfuton, isocarbophos and hexachlorocyclohexane, which has been proved to not be as important as its isomers (Zhou et al., 2001; Zhang et al., 2003; Voutsa et al., 2006). Pesticides such as MCPB, 2,4-DB, mecoprop, dichlorprop, fenoprop, 2,4,5-T were not frequently detected in the drinking water value chain. There was also limited information concerning the occurrence of atrazine and its metabolites, although evidence suggests that they are suspected endocrine disruptors and some of the metabolites have been found to occur in surface waters which might be used as sources for drinking water production. It was, however, decided to keep the metabolites on the list. Pharmaceuticals and personal care products (PPCPs) have limited information to satisfy the PBT criteria. However, most have been found to occur in source water resources. These include compounds such as diclofenac, ibuprofen, amoxicillin, chloramphenicol, sulphamethaxole, lincomycin, trimethoprin and triclosan. These compounds were kept on the PLOCC due to other concerns such as the fact that they are continuously added to the environment and as 'emerging organic contaminants' a lot of research is currently being conducted to establish their public health significance in the aquatic environment. Details are given in Ncube (2009).

Metolachlor was detected in all water samples, from the Vaal Dam to the tap, while atrazine, simazine and terbutylazine were below the detection limits during the wet season. Other contaminants positively identified along the Rand Water drinking water value chain include the disinfection by-products chloroform, bromodichloromethane and dibromochloromethane, and cyanotoxin products 2-methylisoborneol and geosmin. All contaminants which were positively identified occurred at concentrations lower than the recommended drinking water quality guideline or standard when compared with the WHO drinking water guidelines (WHO, 2004), and which thereforedo not constitute a health hazard. The rest of the organic contaminants were either below the detection limit or gave a not detected (nd) result. Aldicarb and its metabolites were detected at a level of $0.02 \mu \mathrm{g} / \mathrm{kg}$ in sediment samples from the Vaal Dam. Heptachlor was detected in fish fat tissue, dieldrin in fat tissue and gonads and p,p'-DDE in fat and gonads during the low-flow season (dry period). During the high-flow season, p,p'-DDE was detected in all 4 fish tissues while deltamethrin, a pyrethroid, was detected in muscle tissue. The results were subjected to statistical analysis as described in preceding sections. The details are given in Ncube (2009).

The assessment of organic contaminants for the occurrence criterion was performed using both multi-residue analysis and target compound analysis. However, most results were either below the limit of detection (LOD), below the method reporting limit (MRL) or non-detected ('nd'). This became a major challenge in data interpretation and application of the occurrence criterion. Measurements below the detection limit raise the degree of uncertainty as this happens as a result of a number of factors. For example, it cannot be reliably asserted that they are statistically different from zero. These is a cause for concern since most organic contaminants on the preliminary priority list occurred at levels lower than the detection limit or were reported as 'not detected'. This constitutes a limitation in implementing the occurrence criterion (Step III of the Protocol). However, due to their properties, it will be advisable to continue monitoring for these organic contaminants, especially in source water. This is due to the fact that organic contaminants are found in the water column at very low concentrations. It has also been observed that investigations or assessments of organic contaminants related to chronic low level exposures or related situations often face the difficult task of dealing with levels of contamination that are hard to detect and/or quantify.

Another limitation for the implementation of the occurrence criterion is the assurance that the non-detection of a parent compound means its absence in the matrix of interest, as it is possible that the compound might have been degraded into metabolites that are either more or less persistent or toxic. In reality, if the parent compound breaks down quickly into its metabolites, it will definitely be detected at lower levels in the matrix of interest or not detected at all. An example is the case of the S-triazine herbicides which are degradable once in the soil or aqueous environment. Transformation products of organic contaminants have the potential to be similarly or even more mobile, persistent or toxic than their parent compounds. These should therefore be included in the assessment of water quality, sediment and biota in order to safeguard human health.

It will therefore be prudent to consider analysing for the degradation products in water, including the parent compounds. Atrazine has been found to have a half-life of 30-90 days in the 
environment. The detection of apparent residues of these herbicides in the drinking water value chain is an indication that they do persist in the aquatic environment, especially source water, and need to be analysed for. Atrazine was detected in most samples, except sediment and fish, in both seasons. The detection of $p, p^{\prime}-D D E$ in most fish tissue is an indicator that the most persistent and bio-accumulative DDT metabolite is p,p'-DDE. Dieldrin was also detected in fish gonads. Dieldrin occurs as a metabolite of the unstable aldrin which is immediately converted to dieldrin once in the environment.

\section{Conclusions}

During the validation exercise, the following was noted: The generic protocol for the selection and prioritisation of organic contaminants for monitoring in the drinking water value chain has been successfully implemented in a prototype drinking water value chain. The area in which the protocol was tested is one of the biggest water utilities in Africa and the assessment covered the whole drinking water value chain from catchment to tap. A priority list of organic contaminants has been identified for use by Rand Water and other water utilities. Organic contaminant monitoring is currently in place. Sampling is done twice a year during the high- and low-flow periods.

The occurrence, potential exposure and human health effects criteria play a major role in selecting and prioritising organic contaminants for monitoring in the drinking water value chain. Industry-specific criteria such as existence of drinking water quality guidelines or standards, availability of capacity for analysis, extent of use of certain organic contaminants in local catchments, relevance of a particular contaminant or group of contaminants to the drinking water industry under local conditions, ease of monitoring, and removal of contaminant during water treatment, also play a significant role during the prioritisation of organic contaminants for monitoring in the drinking water value chain.

Tailor-made prioritisation criteria reflective of the drinking water industry perspective are important, and have proven to be successful in selecting and prioritising organic contaminants for monitoring in the drinking water value chain. The organic contaminants in the current study were successfully prioritised in 3 classes, short-term priority for analysis, medium-term priority for analysis and long-term priority for analysis. This is a very important guide for water utilities to assist in optimising their resources while not compromising the role of public health protection.

\section{Acknowledgement}

The authors would like to thank the Rand Water Board for sampling logistics arrangements and financial assistance during this study.

\section{References}

AOAC INTERNATIONAL (1995) Official Methods of Analysis of AOAC International ( $16^{\text {th }}$ edn.) Volume 1 . AOAC International, Gaithersburg.

BAILEY AJ, VILJOEN FC and VAN ZYL G (1988) A preliminary evaluation of descriptors and odour reference standards recommended by the IAWPRC specialist group on tastes and odours. Water Qual. Bull. 13 (2/3) 84-101.

BALEST L, MASCOLO G, LACONI CDI and LOPEZ A (2008) Removal of endocrine disrupting compounds from municipal wastewater by an innovative biological technology. Water Sci. Technol. 58 (4) 953-956.
BOLTO B and GREGORY J (2007) Organic polyelectrolytes in water treatment. Water Res. 41 2301-2324.

BRAUNE E and ROGERS KH (1987) The Vaal River catchment problems and research needs. South African National Scientific Programmes Report No. 143. 36 pp.

BURGER AEC (2005) Programme on Endocrine Disrupting Compounds (EDCs). Volume I: Strategic Research Plan for Endocrine Disrupters in South African Water Systems. WRC Report No. KV 143/05. Water Research Commission, Pretoria.

BRUWER CA, VAN VLIET HR, SARTORY DP and KEMPSTER PL (1985)An assessment of the Vaal river between Barrage and Douglas Weir. Technical Report TR121, HRI, Department of Water Affairs, Pretoria.

CALDERON RL (2000) The epidemiology of chemical contaminants of drinking water. Food Chem. Toxicol. 38 (1) S13-S20.

CARMICHAEL WW, AZEVEDO MFO, AN JS, MOLICA JR, JOCHIMSEN EM, LAU S, RINEHART KL, SHAW GR and EAGELSHAM GK (2001) Human fatalities from cyanobacterial toxins: Chemical and biological evidence for cyanotoxins. Environ. Health Perspect. 109 (7) 663-668.

CHANG P (2004) Chemical and photolytic degradation of polyacrylamidies used in potable water treatment. M.Sc. thesis, University of South Florida.

CHEEVAPORN V, DUANGKAEW K and TANGKROCK-OLAN N (2005) Environmental occurrence of organochlorines in the East Coast of Thailand. J. Health Sci. 51 (1) 80-88.

COELHO-SOUZA SA, GUIMARAES JRD, MAURO JBN and MARCIO MR (2006) Mercury methylation and bacterial activity associated to tropical phytoplankton. Sci. Total Environ. 364 (1-3) 188-199.

COLVIN VL (2006) The potential environmental impact of engineered nanomaterials. Nat. Biotechnol. 21 (10) 1166-1170.

COOPER RL, STOKER TE, TYREN L and GOLDMAN JM (2000) Atrazine disrupts the hypothalamic control of the pituitary-ovarian function. Toxicol. Sci. 53 297-307.

DoA (DEPARTMENT OF AGRICULTURE) (2000) A guide for the control of household and industrial pests in stored commodities, storage premises, timber, water, human and animal dwellings $\left(1^{\mathrm{s}}\right.$ edn.) National Department of Agriculture, Pretoria, South Africa. $72 \mathrm{pp}$.

DoA (DEPARTMENT OF AGRICULTURE) (2002) A guide for the control of plant pests ( $9^{\text {th }}$ edn.). Department of Agriculture, Pretoria, South Africa. 231 pp.

DoA (DEPARTMENT OF AGRICULTURE) (2003) A guide for the control of plant diseases. Department of Agriculture, Pretoria, South Africa. $131 \mathrm{pp}$.

DoA (DEPARTMENT OF AGRICULTURE) (2004) A guide to the use of herbicides (18 ${ }^{\text {th }}$ edn.). Department of Agriculture, Pretoria, South Africa. $116 \mathrm{pp}$.

DU PREEZ H and VAN BAALEN L (2006) Generic incident management framework for toxic blue-green algal blooms, for application by potable water supplies. Report to Water Research Commission by Rand Water. WRC Report No. TT 263/06 1-82. Water Research Commission, Pretoria.

DU PREEZ HH, HEATH RGM, SANDHAM LA and GENTHE B (2003) Methodology for the assessment of human health risks associated with the consumption of chemical contaminated freshwater fish in South Africa. Water SA 29 (1) 69-90.

EAWAG (2002) Risk factors in water. Swiss Federal Institute for Environmental Science and Technology (EAWAG). EAWAG News 53e (September 2002) 1-8.

ELLIS JB (2006) Pharmaceuticals and personal care products (PPCPs) in urban receiving waters. Environ. Pollut. 144 184-189.

EC (EUROPEAN COMMISSION) (2000) Proposal for a European Parliament and Council Decision Establishing the List of Priority Substances in the Field of Water Policy. European Commission. URL: http://ec.europa.eu/environment/water/water-dangersub/pri substances.htm http://www.europa.eu.int (Accessed 12 January 2007).

FRIMMEL FH (1998) Characterisation of natural organic matter as major constituents in aquatic systems. J. Contamin. Hydrol. 35 (1-3) 201-216. 
GOPAL K, TRIPATHY SS, BERSILLON JL and DUBEY SP (2007) Chlorination by-products, their toxicodynamics and removal from drinking water. J Hazard. Mater. 140 (1-2) 1-6.

HAUKAS M, BERGER V, HOP H and GULLIKSEN B (2007) Bioaccumulation of per and polyfluorinated alkyl substances (PFAS) in selected species from Barent Sea food web. Environ. Pollut. 148 360-371.

HEALTH CANADA (2008) Exisiting substances. Environmental Contaminants - Reports and Publications URL: http://www.hc-sc. ca/ewh-semt/contaminants/existsub/index-eng.php. (Accessed 20 August 2009).

HECQ P, HULSMANN A, HAUCHMAN FS; MCLAIN JL and SCHMITZ F (2006) Drinking Water Regulations. In: Quevauviller $\mathrm{P}$ and Thompson KC (eds.) Analytical Methods for Drinking Water. John Wiley \& Sons. 37 pp.

IEH (INSTITUTE FOR ENVIRONMENT AND HEALTH) (2004) A screening method for ranking chemicals by their fate and behaviour in the environment and potential toxic effects in humans following non-occupational exposure. IEH Web report W14. Medical Research Council Institute for Environment and Health, University of Leicester, UK.

JONES OA, LESTER JN and VOULVOULIS NP (2005) Pharmaceuticals: a threat to drinking water? Trends Biotechnol. 23 (4) 163-167.

KAJ L, ANDERSON J, COUSINS AP, REMBERGER M EKHEDEN Y, DUSAN B, BRORSTRÖM-LUNDÉN E (2005) Results from the Swedish National Screening Programme 2004. Subreport 4: siloxanes. IVL Report B1643. IVL Swedish Environmental Research Institute Ltd., Stockholm. 42 pp.

KARTHIKEYAN KG and MEYER MT (2006) Occurrence of antibiotics in wastewater treatment facilities in Wisconsin, USA. Sci. Total Environ. 361 196-207.

KLAVINŠ M, DIPĀNE J and BABRE K (2001) Humic substances as catalysts in condensation reactions. Chemosphere 44 (4) 737-742.

KIM SD, CHO J, KIM IS and VANDERFORD BJ (2007) Occurrence and removal of pharmaceuticals and endocrine disruptors in South Korean surface, drinking and wastewaters. Water Res. 41 (5) 1013-1021.

KLEIN W, DENZER S, HERRCHEN M and LEPPER P, MÜLLER M, SEHRT R, STORM A and VOLMER J (1999) Revised proposal for a list of priority substances in the context of the Water Framework Directive (COMMPS procedure). Declaration ref. 98/788/3040/ DEB/E1. 1-127. Fraunhoufer-Institut, Schmallenberg, Germany.

KOLPIN DW, SKOPEC M, MEYER MT, FURLONG ET and ZAUGG SD (2004) Urban contribution of pharmaceuticals and other wastewater contaminants to streams during differing flow conditions. Sci. Total Environ. 328 119-130.

KUMAR KS, SAJWAN KS, RICHARDSON JP and KANNAN K (2008) Contamination profiles of heavy metals, organochlorine pesticides, polycyclic aromatic hydrocarbons and alkylphenols in sediment and oyster collected from marsh/estuarine Savannah. GA, USA. Mar. Pollut. Bull. 56 136-162.

KURENKOV VF, GOGOLASHVILI EL, MOLGACHEVA IV and GAISINA AI (2003) Cationic Polymers as Organic Coagulants in Water Treatment at Heat and Electric Power Plants. Russ. J. Appl. Chem. 76 (12) 1951-1954.

LEE JF, LIAO PM, LEE CK, CHAO HP, PENG CL and CHIOU CT (2004) Clay catalysed reactions of coagulant polymers during water chlorination. J. Colloid Interface Sci. 270 (2) 381-387.

LEEUWEN FXR (2000) Safe drinking water: the toxicologist's approach. Food Chem. Toxicol. 38 S51-S58.

LOGANATHAN BG, SAJWAN KS, SINCLAIR E and KUMAR KS (2007) Perfluorinated sulfonates and perfluorinated carboxylates in two wastewater treatment facilities in Kentucky and Georgia. Water Res. 41 4611-4620.

MAHALINGAM R (2004) Interactions between mercury and dissolved organic matter - a review. Chemosphere 55 319-331.

MAJAM S AND THOMPSON P (2007) Polyelectrolyte determination in drinking water. WRC Report No. 1528/01/07. Water Research Commission, Pretoria.

MAJAM S and THOMPSON PA (2006) Polyelectrolyte determination in drinking water. Water SA 32 (5) 705-707.
MEINTJES E, VAN DER MERWE L and DU PREEZ JL (2000) Qualitative and quantitative evaluation of estrogen and estrogenmimicking substances in the water environment. WRC Report No. 742/1/00. Water Research Commission, Pretoria. 66 pp.

MIDDLETON BS and ROSEN AA (1956) Organic contaminants affecting the quality of water. Public Health Rep. 71 (11) 1125-1133.

MIÈGE C, CHOUBERT JM, RIBEIRO L and EUSÈBE M (2008) Removal efficiency of pharmaceuticals and personal care products with varying wastewater treatment processes and operating conditions-conception of a database and first results. Water Res. Technol. 57 (1) 49-56.

$\mathrm{MoH}$ (2008) Ministry of Health Drinking Water Standards for New Zealand 2005 (Revised 2008). New Zealand Ministry of Health. ISBN: 978-0-478 318098.

MOUDGAL CJ, LIPSCOMB JC and BRUCE RM (2000) Potential health effects of drinking water disinfection by-products using quantitative structure toxicity relationship. Toxicology 147 109-131.

NCUBE EJ (2009) Selection and prioritization of organic contaminants for monitoring in the drinking water value chain. $\mathrm{PhD}$ thesis, University of Pretoria, Pretoria. URL: http://upetd.up.ac.za/thesis/ available/etd-10092010-145042.

NCUBE EJ, VOYI K and DU PREEZ H (2011) Selection and prioritization of organic contaminants for monitoring in the drinking water value chain. Proc. $35^{\text {th }}$ WEDC International Conference, The future of water, sanitation and hygiene: Innovation, adaption and engagement in a changing world, 6-8 July 2011, Loughborough, UK. Paper ID\# 1176.

NHMRC (2004) Australian Drinking Water Guidelines. National Health and Medical Research Council (Australia), Canberra. URL: http://www.health.gov.au/nhmrc/publications/synopses/eh19syn. $\underline{\text { htm }}$ (Accessed May 2007).

NIQUETTE P, MONETTE F, AZZOUZ A and HAUSTER R (2004) Impacts of substituting aluminium-based coagulants in drinking water treatment. Water Qual. Res. J. Can. 39 (3) 303-310.

OBERDÖRSTER E, ZHU S, BLICKLEY TM and MCCLELLANGREEN P (2006) Ecotoxicology of carbon-based engineered nanoparticles: effects of fullerene $\left(\mathrm{C}_{60}\right)$ on aquatic organisms. Carbon 44 1112-1120.

OKUDA T, KOBAYASHI YA, NAGAO R and YAMASHITA N (2008) Removal efficiency of 66 pharmaceuticals during wastewater treatment process in Japan. Water Res. Technol. 57 (1) 65-67.

PACHECO ML, PEÑA-MÉNDEZ EM and HAVEL J (2005) Supramolecular interactions of humic acids with organic and inorganic xenobiotics studied by capillary electrophoresis. Chemosphere $\mathbf{5 1}$ 95-108.

POLDER A, VENTER B, SKAARE JU and BOUWMAN H (2008) Polybrominated diphenyl ethers and HBCD in bird eggs of South Africa. Chemosphere 73 148-154.

RAND WATER (2006) Area of supply. URL: http://www.randwater. co.za/AboutUs/Pages/AreaOfSupply.aspx (Accessed 30 September 2009).

RICHARDSON SD (2003) Disinfection by-products and other contaminants in drinking water. Trends Anal. Chem. 22 (10) 666-684.

RICHARDSON SD, SIMMONS JE and RICE G (2002) The next generation. Environ. Sci. Technol. 36 197A-205A

RIER S and FOSTER WG (2002) Environmental dioxins and endometriosis. Toxicol. Sci. 200270 161-170.

RISSATO SR, GALHIANE MS, XIMENES VF and DE ANDRADE RMB (2006) Organochlorine pesticides and polychlorinated biphenyls in soil and water samples in the north eastern part of São Paulo State, Brazil. Chemosphere 65 1949-1958.

RODRIGUEZ-MOZAZ S, LÓPEZ DE ALDA MJ and BARCELÓ D (2006) Fast and simultaneous monitoring of organic pollutants in a drinking water treatment plant by a multi-analyte biosensor followed by LC-MS validation. Talanta 69 377-384.

ROWE BL, TOCCALINO PL, MORAN MJ, ZOGORSKI JS and PRICE J (2007) Occurrence and potential human health relevance of organic contaminants in the drinking water from domestic wells, United States. Environ. Health Perspect. 115 (11) 1539-1546. 
SABS (2000) Method No. 018/2000. Determination of 2,4-D residues in various citrus and relevant matrices. South African Bureau of Standards, Pretoria, South Africa.

SABS (2001) Method 021/2001. Multi-residue method for the determination of organochlorine and synthetic pyrethroid pesticide residues in animal tissue. South African Bureau of Standards, Pretoria, South Africa.

SABS (2006) The South African Drinking Water Quality Standard, SANS 241: 2006 Edition 6.1. South African Bureau of Standards, Pretoria, South Africa.

SADIQ R and RODRIGUEZ MJ (2004) Disinfection by-products (DBPs) in drinking water and predictive models for their occurrence: a review. Sci. Total Environ. 321 21-46.

SHARPE M (2003) High on pollution: drugs as environmental contaminants. J. Environ. Monit. 5 42N-46N.

SIMMONS JE, TEUSCHLER LK, GENNINGS C, SPETH TF, RICHARDSON SD, MILTNER RJ, NAROTSKY MG, SCHENCK KD, HUNTER III ES and HERZBERG RC (2004) Component based and whole-mixture techniques for addressing the toxicity of drinking water disinfection by-product mixtures. J. Toxicol. Environ. Health 67 (A) 741-754.

SKJEVRAK I, DUE A, GJERSTAD KO and HERIKSTAD H (2003) Volatile organic components migrating from plastic pipes (HDPE, PEX and PVC) into the drinking water. Water Res. 37 (8) 1912-1920.

SKJEVRAK I, LUND V, ORMEROD K and HERIKSTAD H (2005) Volatile organic compounds in natural biofilm in polyethylene pipes supplied with lake water and treated water from the distribution network. Water Res. 39 4133-4141.

STACKELBERG PE, GIBS J, FURLONG ET and MEYER MT (2007) Efficiency of conventional drinking water treatment process in removal of pharmaceuticals and other organic compounds. Sci. Total Environ. 377 255-272.

TITSHALL LW and HUGHES JC (2005) Characterisation of some South African water treatment residues and implications for land application. Water SA 31 (3) 299-308.

UNEP (2001) Stockholm Convention on Persistent Organic Pollutants (POPs). URL: http://www.chem.unep.ch/sc (Accessed 13 May 2004). United Nations Environment Programme, Geneva.

USEPA (1984) EPA Method Study 30 Method 625. Base/Neutrals Acids and Pesticides. EPA 600/54-84-84-053. Environmental Monitoring and Support Laboratory, Cincinnati OH 45628.

USEPA (1996a) EPA Method 8260. Volatile organic compounds by gas chromatography and mass spectrometry (GC/MS). URL: http:// www.epa.gov/osw/hazard/testmethods/sw846/pdfs/8260b.pdf.

USEPA (1996b) Method 5021. Volatile organic compounds in soils and other solid matrices using equilibrium headspace analysis. URL: http://www.epa.gov/osw/hazard/testmethods/sw846/pdfs/5021.pdf.

USEPA (2000) Technical Background Information for the Unregulated Contaminant Monitoring Regulation. EPA 815-R-99-007, March 2000. United States Environmental Protection Agency. Office of Water, Washington, DC.

USEPA (2007) Method 8270. Semivolatile organic compounds by gas chromatography and mass spectrometry (GC/MS). URL: http:// www.epa.gov/osw/hazard/testmethods/sw846/pdfs/8270d.pdf.

USEPA (2008) Drinking Water Contaminant Candidate List 3-Draft; Notice. Federal Register 73 (35) 1-28.
VAN STEENDEREN RA, THERON SJ and HASSETT AJ (1987) The occurrence of organic micro pollutants in the Vaal River between Grootdraai Dam and Parys. Water SA 13 (4) 209-213.

VON GUNTEN U (2003) Ozonation of drinking water: Part II Disinfection and by-product formation in the presence of bromide, iodide or chlorine. Water Res. 37 1469-1487.

VOULVOULIS N (2004) Environmental risk management for pharmaceutical compounds. Proc. $24^{\text {th }}$ International Symposium on Halogenated Environmental Organic Pollutants and POPs (Dioxin 2004), September 2004, Berlin. 3481-3489.

VOUTSA D, HARTMAN P, SCHAFFNER C and GIGER W (2006) Benzotriazoles, alkylphenols and Bisphenol A in municipal wastewaters and in the Glatt River, Switzerland. Environ. Sci. Pollut. Res. 13 (5) 333-341.

WEBB S, TERNES T, GILBERT M and OLEJNICZAK (2003) Indirect human exposure to pharmaceuticals via drinking water. Toxicol. Lett. 142 (3) 157-167.

WEBER S, KHAN S AND HOLLENDER J (2006) Human risk Assessment of organic contaminants in reclaimed wastewater used for irrigation. Desalination 187 53-64.

WENZEL DA, MÜLLER J and TERNES T (2003) Study on endocrine disruptors in drinking water. Final Report ENV.D1/ ETU/2000/0083. Fraunhofer Institute for Molecular Biology and Applied Ecology (IME); ESWE Institute for Water Research and Water Technology (JOGU-ESWE). Schmallenberg and Wiesbaden, Germany. I-VIII.

WIEGAND C and PFLUGMACHER S (2005) Ecotoxicological effects of selected cyanobacterial secondary metabolites a short review. Toxicol. Appl. Pharmacol. 203 201-218

WOO YT, LAI D, McLAIN JL, MANIBUSAN MK and DELLARCO $\mathrm{V}$ (2002) Use of mechanism-based structure-activity relationships analysis in carcinogenic potential ranking for drinking water disinfection by-products. Environ. Health Perspect. 110 (1) 75-87.

WHO (WORLD HEALTH ORGANIZATION ) (2004) Guidelines for Drinking Water Quality ( $3^{\text {rd }}$ edn.). World Health Organization, Geneva. www.who.int/water sanitation health/dwa/en/

ZHANG Z, DAI M, HONG H, ZHOU JL and YU G (2002) Dissolved insecticides and polychlorinated biphenyls in the Pearl River and South China Sea. R. Soc. Chem. 4 922-928.

ZHANG Z, HUANG J and YU G (2004) Occurrence of PAHs, PCBs and organochlorine in the Tonghui River of Beijing. China Environ. Pollut. 130 (2) 249-261.

ZHANG ZL, HONG HS, ZHOU JL and YU G (2003) Occurrence and behaviour of organophosphorus insecticides in the River Wuchuan, Southeast China. J. Environ. Monit. 4 498-504.

ZHOU JL, MASKAOVI K, QIU YW and HONG HS (2001) Polychlorinated biphenyl congeners and organochlorine insecticides in the water column and sediments of Daya Bay. China Environ. Pollut. 113 373-384.

ZHU S, OBERDÖRSTER E and HAASCH ML (2006) Toxicity of an engineered nanoparticle (fullerene, C60) in two aquatic species, Daphnia and fathead minnow. Mar. Environ. Res. 62 55-59.

ZIMMERMAN MJ (2005) Occurrence of organic wastewater contaminants, pharmaceuticals and personal care products in selected water supplies, Cape Cod, Massachusetts. June 2004: U.S. Geological Survey Open-File Report 2005-1206. 16 pp. 
http://dx.doi.org/10.4314/wsa.v38i4.3 Available on website http://www.wrc.org.za

ISSN 0378-4738 (Print) = Water SA Vol. 38 No. 4 July 2012 ISSN 1816-7950 (On-line) = Water SA Vol. 38 No. 4 July 2012 